University of Wollongong

Research Online

Faculty of Science - Papers (Archive)

Faculty of Science, Medicine and Health

$25-6-2006$

\title{
Physiological Traits of Organisms in a Changing Environment
}

F. Hennion

Universite de Rennes, France

A. H. Huiskes

Netherlands Institute of Ecology

Sharon A. Robinson

University of Wollongong, sharonr@uow.edu.au

P. Convey

British Antarctic Survey, UK

Follow this and additional works at: https://ro.uow.edu.au/scipapers

\section{Recommended Citation}

Hennion, F.; Huiskes, A. H.; Robinson, Sharon A.; and Convey, P.: Physiological Traits of Organisms in a Changing Environment 2006.

https://ro.uow.edu.au/scipapers/5

Research Online is the open access institutional repository for the University of Wollongong. For further information contact the UOW Library: research-pubs@uow.edu.au 


\title{
Physiological Traits of Organisms in a Changing Environment
}

\begin{abstract}
[Extract] Antarctic ecosystems represent one extreme of the continuum of environmental conditions across the planet. To our eyes, the environment appears harsh but, even though terrestrial biological diversity is restricted, a wide range of life is present and, locally, thrives. In the Antarctic, unusually, environments exist in which physical characteristics are dominant and overcome biological considerations. These are at the extreme ends of the ranges of many characteristics (temperature, snow, ice and solar radiation) found across environments globally. However, the Antarctic is also a large continent, comparable in area to continental Europe, and further surrounded by the cold Southern Ocean, within which lie a ring of subantarctic islands. Together, these islands and the continent give a natural environmental gradient with which to study the biological impacts of climate variables. Antarctica is also a focus for studies of responses to regional and global change (eg Bergstrom and Chown 1999, Convey 2001,2003 , Robinson et al. 2003). Some of the fastest changing regions on earth (air temperatures along the western Antarctic Peninsula and Scotia Arc) are found here (King and Haranzogo 1998, Skvarca et al. 1998, Smith 2002, Quayle et al. 2002, 2003). Evaluations of change in this area are expected to provide a vital 'early warning system' for change consequences worldwide (Convey et al. 2003a, b). This chapter addresses an area central to our ability to understand and evaluate biotic responses to climate change predictions - that of organism physiology.

\section{Publication Details}

This book chapter was published as Hennion, F, Huiskes, A, Robinson, S and Covey, P, Physiological Traits of Organisms in a Changing Environment, in Bergstrom, DM, Convey, P and Huiskes, A (eds), Trends in Antarctic Terrestrial and Limnetic Ecosystems: Antarctica as a Global Indicator, Springer, 2006, 129-159. Copyright Springer 2006.
\end{abstract}




\title{
7. PHYSIOLOGICAL TRAITS OF ORGANISMS IN A CHANGING ENVIRONMENT
}

\author{
F. HENNION \\ Impact des Changements Climatiques, UMR 6553, Centre National de \\ la Recherche Scientifique - Université de Rennes 1 \\ Campus de Beaulieu \\ F-35042 Rennes cedex, France \\ Francoise.Hennion@univ-rennes1.fr
}

\author{
A.H.L. HUISKES \\ Unit for Polar Ecology, \\ Netherlands Institute of Ecology (NIOO-KNAW) \\ P.O. Box 140, 4400 AC Yerseke, The Netherlands \\ A.Huiskes@nioo.knaw.nl
}

\section{S. ROBINSON}

Institute for Conservation Biology,

University of Wollongong

Northfields Avenue

Wollongong, NSW 2522, Australia

sharonr@uow.edu.au

P. CONVEY

British Antarctic Survey, Natural Environment Research Council

High Cross, Madingley Road

Cambridge CB3 OET, United Kingdom

p.convey@bas.ac.uk 


\section{Introduction}

Antarctic ecosystems represent one extreme of the continuum of environmental conditions across the planet. To our eyes, the environment appears harsh but, even though terrestrial biological diversity is restricted, a wide range of life is present and, locally, thrives. In the Antarctic, unusually, environments exist in which physical characteristics are dominant and overcome biological considerations. These are at the extreme ends of the ranges of many characteristics (temperature, snow, ice and solar radiation) found across environments globally. However, the Antarctic is also a large continent, comparable in area to continental Europe, and further surrounded by the cold Southern Ocean, within which lie a ring of subantarctic islands. Together, these islands and the continent give a natural environmental gradient with which to study the biological impacts of climate variables.

Antarctica is also a focus for studies of responses to regional and global change (eg Bergstrom and Chown 1999, Convey 2001, 2003, Robinson et al. 2003). Some of the fastest changing regions on earth (air temperatures along the western Antarctic Peninsula and Scotia Arc) are found here (King and Haranzogo 1998, Skvarca et al. 1998, Smith 2002, Quayle et al. 2002, 2003). Evaluations of change in this area are expected to provide a vital 'early warning system' for change consequences worldwide (Convey et al. 2003a, b). This chapter addresses an area central to our ability to understand and evaluate biotic responses to climate change predictions - that of organism physiology.

\section{Antarctic climate change}

Features of climate change as seen in the Antarctic are described in Convey this volume and are summarised briefly here. Two non-connected aspects of Antarctic climate change have received most attention - the rapid temperature increases that have been well documented along the Antarctic Peninsula and Scotia Arc and are observed to a lesser extent elsewhere and the seasonal formation in the austral spring of the Antarctic 'ozone hole'. At a continental scale some areas, particularly of inland continental Antarctica and parts of Victoria Land, are also thought to have experienced cooling over the same period, although data are sparse. In addition to any direct biological consequences of changes in temperature, indirect consequences may also be significant - for instance, temperature increases in either winter or summer may lead to a shortening of the winter season - while temperature changes will clearly also be linked with the processes controlling water availability in terrestrial habitats.

Water availability can be more important even than temperature in controlling biological activity in Antarctic terrestrial habitats (Kennedy 1993, Block 1996). In the subantarctic in particular, recent changes in precipitation patterns potentially 
have greater biological significance than the concurrent changes in temperature. Clearly, changes in precipitation patterns will impact water availability, although this is likely to be seen most directly in the subantarctic and parts of the maritime Antarctic (during summer), when the majority of precipitation falls as rain rather than snow and is immediately available to terrestrial biota. Summer thawing of seasonal snow banks and runoff from permanent glaciers also provide liquid water to terrestrial habitats, hence changes in the timing and magnitude of winter precipitation events, and the timing of thaws, will also be important. Consequences may also include a decrease in water availability, in instances where precipitation reduces, or finite resources of snow or ice are exhausted. Trends of both increasing and decreasing precipitation, identified in datasets covering up to the last six decades, are being seen at a variety of maritime and subantarctic locations.

The potential biological significance of seasonal ozone depletion is linked with the associated increase in shorter wavelength UV-B radiation reaching the Earth's surface. However, it is the timing of this increase rather than the absolute magnitude that is important. During periods of maximum ozone loss (typically October and November, during the austral spring) the intensity of UV-B radiation at ground level is similar to that normally experienced in mid-summer. However, early in the spring, exposed biota may be unable to respond, as they are yet to resume normal physiological activity after winter.

\section{ORGANISMS UNDER INCREASED RADIATION}

The potential effects of UV-B radiation on phototrophic organisms may be grouped into three areas: (a) changes in photosynthesis and growth (eg through trade-offs with reproductive capacity and biomass) (Teramura and Ziska 1996) (b) increased investment in UV-B absorbing or screening compounds (Karentz et al. 1991a,b) and (c) DNA damage, repair and photoreactivation (Lud et al. 2001a). Mobile organisms, such as cyanobacteria, can move to deeper layers in the soil to avoid radiative stress (Wynn-Williams 1994), while sessile organisms are particularly exposed to UV-B radiation. However, despite the clear effects seen in laboratory manipulations, those field studies that find effects generally report these to be much more minor, while others often report no detectable consequences (Jackson and Seppelt 1997, Montiel et al. 1999, Day et al. 1999, Huiskes et al. 1999, 2001, Lud et al. 2001a, Rozema et al. 2001).

Sessile phototrophic organisms such as lichens can not avoid incident solar radiation completely and they must make a trade-off between receiving sufficient levels of PAR and appreciable doses of UV-B (Day 2001). Microniche selection also plays a part, in that many utilise partially protected crevices and fissures, or locations that are protected by snow cover during the critical period (Cockell et al. 2002). To some extent they can also utilise a passive avoidance strategy: being poikilohydric, the periods when they are moist and active generally occur in the mornings or in the evenings, when UV radiation levels are low. However, it is also 
important to quantify the potential for uncontrolled damage during inactive periods, when repair is not possible.

\section{CHANGES IN PHOTOSYNTHESIS AND GROWTH}

Day and co-workers (Day et al. 1999, 2001, Xiong and Day 2001, Ruhland and Day 2000, 2001) have completed an extensive field manipulation study near Palmer Station (Anvers Island, western Antarctic Peninsula), separating the influence of UV-B and other environmental variables on the growth and ecophysiology of the two Antarctic flowering plants, Colobanthus quitensis (Kunth) Bartl. and Deschampsia antarctica Desv. Relative to ambient controls, exposure to solar UV-B from spring to mid-summer led to $11-22 \%$ less biomass and a $24-31 \%$ decrease in leaf area. Rates of photosynthesis were reduced when expressed relative to chlorophyll content or dry mass, but not relative to leaf area, through the development of thicker leaves containing more photosynthetic and screening pigments. Exposure to UV-B also led to reductions in quantum yield of photosystem II, based on fluorescence measurements of adaxial leaf surfaces and impaired photosynthesis in the upper mesophyll layer. The latter was suggested to be associated with light-independent enzymatic limitations. In C. quitensis, exposure to solar UV-B led to reductions in leaf longevity, branch production, cushion diameter growth, above-ground biomass and thickness of the non-green cushion base and litter layer. Exposure to UV-B also influenced patterns of reproductive investment, accelerating the development of reproductive structures and increasing the number of panicles (D. antarctica) and capsules (C. quitensis). Seed viability appeared to remain unchanged. In a similar field manipulation study in the Windmill Islands, East Antarctica, gametophytes of the moss Grimmia antarctici growing under near ambient UV radiation had a higher density of leaves than those growing under reduced UV radiation and there was evidence of morphological changes in moss exposed to ambient UV radiation (Robinson et al. 2005) (Fig. 1). However, no evidence for changes to photosynthetic parameters were detected in this species and rates of growth were too slow for any difference to be apparent over a 14 month period. Also other studies have failed to detect differences in photosynthetic parameters related to UV-B exposure. Rozema et al. (2001) reported no difference in net photosynthesis of Deschampsia antarctica treated with different levels of UV-B radiation in a growth chamber. They also showed a reduction in the length of shoots of $D$. antarctica when grown under experimental conditions but, under field conditions, no difference in shoot length or reproductive biomass was detected. Lud et al. (2001b) found no changes in photosynthetic activity of lichens and mosses either in field measurements or under controlled conditions. This was equally true for net photosynthesis, maximum PSII quantum efficiency and effective PSII quantum efficiency. Likewise, Montiel et al. (1999) found no changes in $D$. antarctica and $C$. quitensis and George et al. (2001) reported that some 
cyanobacteria were unaffected by UV-B radiation. Some other studies however reported evidence for a negative effect of UV-B radiation on photosynthesis of certain Antarctic species, including some cyanobacteria (George et al. 2001), mosses (Montiel et al. 1999) and a terrestrial alga (Post and Larkum 1993).
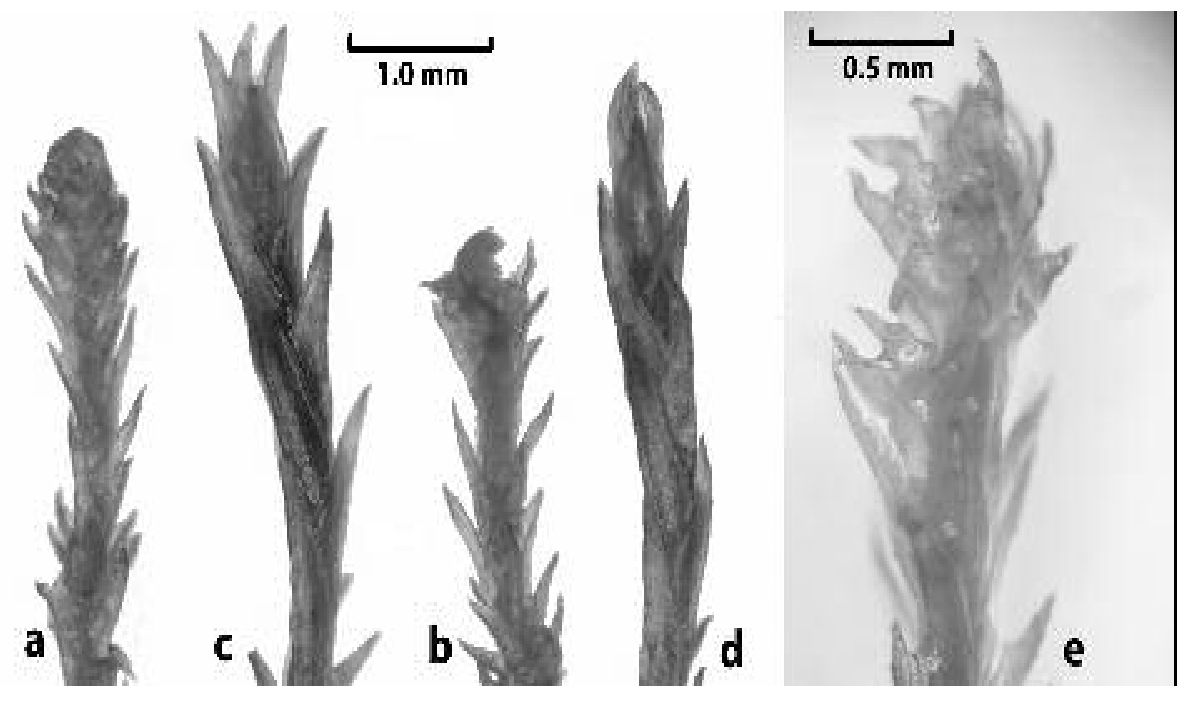

Figure 1. Comparison of gametophytes of Grimmia antarctici showing the normal leaf morphology $(c$ and $d)$ and atypical leaf morphology $(a$ and $b)$, enlarged (e). Atypical leaves were characterized by short length and blunted leaf tips and were twice as common in plants grown under near ambient rather than reduced UV-B radiation (from Robinson et al. 2005).

\section{INCREASES IN UV-B ABSORBING COMPOUNDS}

A variety of UV-B absorbing compounds are found in Antarctic phototrophic organisms (eg Karentz et al. 1991a,b, Adamson and Adamson 1992). Phenylpropanoids produced by the shikimate pathway are thought to be predominant, often in combination with the acetate-malonate pathway (Day 2001). These pathways are responsible for the synthesis of various phenolic compounds (hydroxycinnamic acids, flavonoids, lignins and tannins). Key enzymes in these pathways are induced by light, both visible and UV (Beggs and Wellmann 1994). Flavonoids are present in D. antarctica (Webby and Markham 1994) and some moss species (Webby et al. 1996). They often accumulate in the epidermis, where, in higher plants, over $90 \%$ of incident UV- radiation is attenuated (Robberecht and Caldwell 1978). Recent research (Nybakken et al. 2004a,b) suggests that epidermal screening may be a constitutive feature, with little or no evidence for any dynamic response in effectiveness in Arctic and alpine plants. The only direct evidence 
available for plants having a dynamic ability to respond to incident levels of UV-B radiation over ecologically realistic timescales is from studies of three Antarctic mosses (Newsham et al. 2002, Newsham 2003) exposed to natural variations under the Antarctic ozone hole. These studies found that screening pigment concentrations were best correlated with levels of UV-B radiation experienced during the preceding $24 \mathrm{~h}$. Species variation has also been shown for co-occurring Antarctic mosses, with the endemic species Grimmia antarctici possessing low levels of UV-B screening pigments whilst the two cosmopolitan species Ceratodon purpureus and Bryum pseudotriquetrum have intermediate and higher concentrations respectively (Dunn 2000, Lovelock and Robinson 2002, Robinson et al. 2005). In only one of these species, B. pseudotriquetrum, was evidence found that UV screening pigments correlate with UV radiation doses (Dunn 2000, Robinson et al. 2005). Experimental manipulations demonstrate that flavonoid synthesis may be enhanced by both UV-B radiation (Meykamp et al. 2001) and UV-A and visible wavelengths (Bornman and Sundby-Emanuelsson 1995). Concentrations of UV-B absorbing compounds were found to be higher in seedlings of Colobanthus quitensis exposed to natural UV-B levels in the field compared to those under UV-B absorbing screens (Ruhland and Day 2001).

Other secondary UV-screening compounds such as mycosporine-like amino acids (MAAs) may also be involved in UV-B responses. MAAs consist of a substituted cyclohexenone linked with an amino acid or an amino alcohol, and are found in many different organisms including fungi, eukaryotic algae, corals and starfish, Antarctic microalgae and cyanobacteria (Karentz et al. 1991b, GarciaPichel and Castenholz 1993, Ishikura et al. 1997, George et al. 2001). Prasiola crispa, a common Antarctic terrestrial green alga, contains low concentrations of UV-B absorbing compounds (including an unknown MAA) (Post and Larkum 1993, Hoyer et al. 2001, Lud et al. 2001a). However, chlorophyll concentration and photosynthesis in this alga are depressed when exposed to UV-B radiation (Post and Larkum 1993, Jackson and Seppelt 1997).

Lichens also contain a high proportion of secondary products, some not found in other groups (Huneck et al. 1984). Many are synthesised by the mycobiont and are often deposited as crystals on the surfaces of hyphae and phycobiont cells (Honegger 1986). Their role (if any) in photoprotection is unclear. For instance, although Solhaug and Gauslaa (1996) confirmed the photoprotective role of parietin in Xanthoria parietina, this was not the case in two other lichens examined. Swanson and Fahselt (1997) and Swanson et al. (1996) found a negative correlation between exposure to UV-B and thallus contents of lichen phenolics.

\section{PHOTOSYNTHETIC AND PHOTOPROTECTIVE PIGMENTS IN ANTARCTIC PLANTS}

In Antarctica, even with relatively low solar zenith angles, irradiance levels can be 
both very high and variable, being strongly influenced by meteorological conditions and the high surface albedo of surrounding snow and ice. Several Antarctic plants have photosynthetic pigment characteristics more common to high light plants. For example in three Antarctic moss species the photoprotective xanthophyll cycle and $B$ carotene pigments comprised between $32-42 \%$ of the total carotenoid pool, which is comparable to species grown under high light conditions (Demmig-Adams and Adams 1992, Dunn 2000, Robinson et al. 2001, Lovelock and Robinson 2002). In addition, $15-80 \%$ of the xanthophyll cycle pigments remain in their photoprotective forms even after periods under low light conditions. This suggests the use of an 'insurance' strategy, ie that plants experience frequent periods of high light under temperature conditions that preclude use of this energy for photosynthesis, hence requiring the pigments to absorb excess energy (Schlensog et al. 1997, Verhoeven et al. 1998, Dunn 2000, Lovelock and Robinson 2002).

Photoprotective pigments, such as zeaxanthin, are important in protecting certain Antarctic mosses from the negative effects of freeze-thaw events (Lovelock et al. 1995a,b). It has also been suggested that these antioxidant pigments play a role in protection from UV-B exposure, since some Antarctic bryophytes and higher plants produce increased levels of carotenoids in response to high, ambient UV-B radiation (Dunn 2000, Xiong and Day 2001, Newsham et al. 2002, Newsham 2003, Robinson et al. 2003). Some studies of Antarctic mosses further suggest that plants with low levels of UV-B pigments have correspondingly higher levels of photoprotective pigments (Dunn 2000, Robinson et al. 2001, 2003).

Chlorophyll a:b ratios of Antarctic mosses are high ( $>3.2)$ and more similar to those found in higher plants growing in high light environments, than those found in temperate and subarctic mosses which exhibit shade characteristics (Balo 1967, Martin 1980, Martin and Churchill 1982, Kershaw and Webber 1986, McCall and Martin 1991, Barsig et al. 1998, Gehrke 1998). However, evidence that chlorophyll bleaching occurs in exposed environments has been found in some species. Grimmia antarctici turf growing on exposed ridges and under ambient UV radiation had significantly less chlorophyll than moss in sheltered valleys or under reduced UVradiation (Robinson et al. 2005). In addition, despite having higher levels of UV-B screening pigments, chlorophyll b content was lowered in Colobanthus quitensis seedlings exposed to natural UV-B levels in the field (Ruhland and Day 2001).

\section{DNA-DAMAGE AND PHOTOREACTIVATION}

DNA is a vulnerable component of the living cell and is more sensitive to UV-B damage than the photosynthetic process (Lud et al. 2001a,b). Cyclobutane pyrimidine dimer formation occurs when DNA is damaged by UV-B radiation (Buma et al. 1995), leading to the activation of repair mechanisms, including photoreactivation, excision of dimers, recombinational filling of gaps and resynthesis of DNA. Repair processes can be inhibited by low temperatures (Pakker et al. 2000), which might imply that higher damage levels would be expected in 
Antarctic biota exposed to UV-B radiation at low temperature. The natural growth form of some species, such as the multi-layered thallus of the alga Prasiola crispa and the accumulation of dead cells on the thallus surface reported for some lichen species (Crittenden 1998) could be a form of protection against UV-B (both in the context of DNA damage and other biochemical processes) as suggested previously for mat-forming cyanobacteria (Margulis et al. 1976).

There have been very few studies of DNA damage in Antarctic terrestrial biota. Damage levels encountered in the moss Sanionia uncinata, alga Prasiola crispa and experimental microbial dosimeters are substantially lower than those found in marine organisms (Buma et al. 2001, George et al. 2002). In P. crispa damage does not increase linearly with dose as found for unicellular marine organisms (Buma et al. 1995), indicating repair of DNA damage during the day under ambient UV-A and PAR (Lud et al. 2001a) (Fig. 2). Even after exposure to high levels of UV-B, repair overnight is sufficient to prevent accumulation of dimers and low levels of DNA damage do not appear to affect growth of P. crispa.

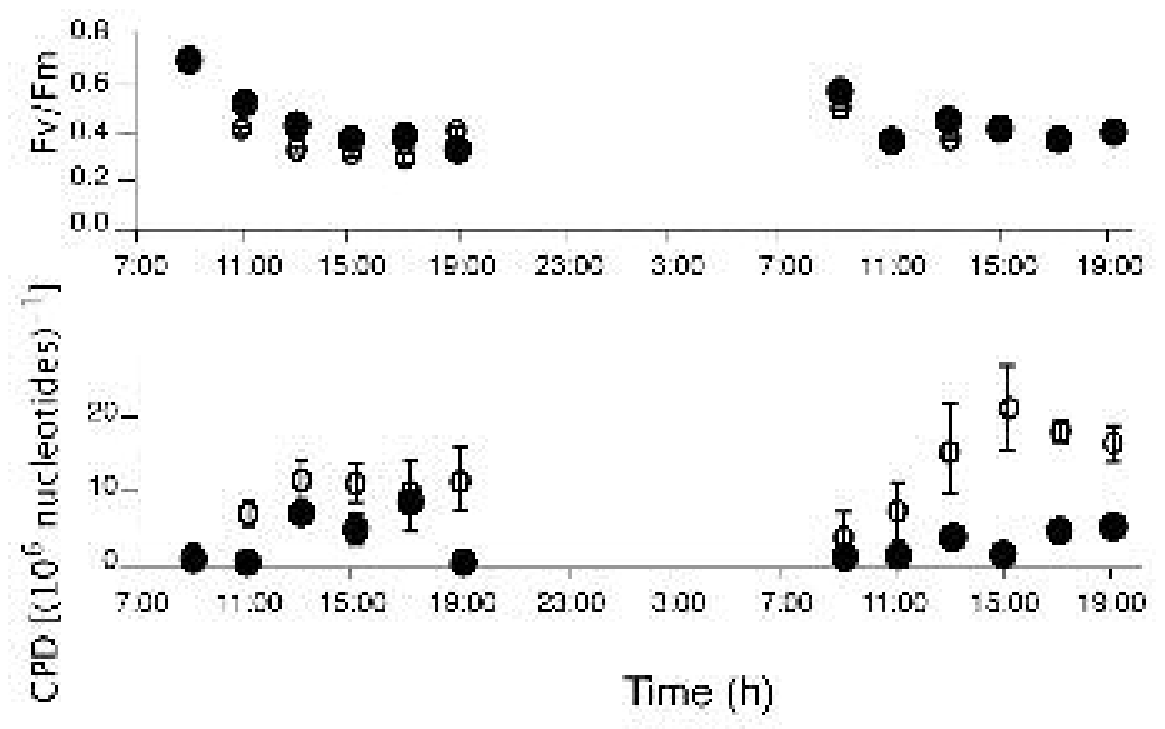

Figure 2. Values of maximum PSII quantum efficiency $(F v / F m)(a)$ and cyclobutyl pyrimidine dimer $(C P D)$ frequencies, indicating DNA damage (b) of Prasiola crispa under UV-Minilamps with mylar filters (blocking UV-B transmission), respectively, Cellulose Acetate (CA) filters (transparent to $U V-B$ ). Filled circles represent samples exposed to ambient $U V-B$ (mylar lamp), open circles represent samples exposed to enhanced UV-B (CA lamp). The symbols show mean and standard deviation. Note the overnight decrease in CPD frequencies, indicating the presence of repair mechanisms (Adapted from Lud et al. 2001b). 


\section{CONSEQUENTIAL EFFECTS ON FAUNA AND THROUGH FOOD WEBS}

The direct effects of UV-B radiation on plants already described above may have much wider consequential impacts. Changes in the concentrations and/or types of protective pigments can affect the quality of plant or microbial material as a food resource, with implications throughout the food web. In a multi-trophic level and multiple stress field manipulation study completed at Palmer Station, Anvers Island, Day et al. (1999 2001) identified a range of biochemical and morphological changes resulting particularly from exposure to UV-B. Convey et al. (2002) further demonstrated consequential negative impacts of UV-B exposure on the associated arthropod populations, proposing to link these with altered diet quality. Perhaps surprisingly, these studies also found that warming, while increasing growth of plants, had a negative influence on some invertebrate populations, although this may be linked with increased drying stresses at higher temperatures.

Field manipulation experiments focussing on temperature and UV radiation are known to lead to changes in leaf or shoot production, leaf length, or foliar cover, all of which may affect vegetative growth form (Smith 1990, 2001, Day et al. 1999, 2001, Sullivan and Rozema 1999, Ruhland and Day 2000). With the simple, cryptogamic, vegetation characteristic of maritime and continental Antarctic habitats, even subtle changes in growth form will alter habitat structure and microclimate characteristics. While the consequences of such changes have not been studied in the Antarctic, the fundamental importance of addressing climate change consequences across multiple trophic levels is recognised, as it is clear that subtle effects at one level may combine or interact to produce much greater consequences elsewhere in the food web (Day 2001, Searles et al. 2001).

\section{Antarctic plants under changing temperature}

\section{PHOTOSYNTHESIS}

Antarctic and subantarctic photosynthetic autotrophs maintain photosynthesis at low temperatures, with some being active well below $0^{\circ} \mathrm{C}$. For instance, the subantarctic crucifer Pringlea antiscorbutica, the grass Poa cookii and the Rosaceae Acaena magellanica and A. tenera sustain photosynthesis throughout the year, even during the coldest days when the temperature remains close to $0^{\circ} \mathrm{C}$ (Bate and Smith 1983 , Smith 1984, Aubert et al. 1999a). Photosynthetic activity has been reported in continental Antarctic lichens below $-10^{\circ} \mathrm{C}$ (Schroeter et al. 1994). However, during summer photosynthetic organs often achieve temperatures well above zero and optimum temperatures for photosynthesis are correspondingly higher, ranging from $10-12^{\circ} \mathrm{C}$ in Deschampsia antarctica from Signy Island and the Antarctic Peninsula (Edwards and Smith 1988, Xiong et al. 1999), $12^{\circ} \mathrm{C}$ in Poa cookii from Marion 
Island (Bate and Smith 1983), $15^{\circ} \mathrm{C}$ in Pringlea antiscorbutica at Iles Kerguelen (Aubert et al. 1999a), $19^{\circ} \mathrm{C}$ in Colobanthus quitensis from Signy Island (Edwards and Smith 1988) and up to $20-25^{\circ} \mathrm{C}$ in a variety of maritime moss species (Rastorfer 1972, Green et al. 1999, 2000, Schroeter et al. 1997, Pannewitz et al. 2003). Some species additionally show plasticity in their optimal temperature. When grown at temperatures above those experienced in the field, the optimal temperature for Drepanocladus uncinatus (now known as Sanionia uncinata) remained at $15{ }^{\circ} \mathrm{C}$, whilst that for Polytrichum alpestre increased from $5-10^{\circ} \mathrm{C}$ to $15^{\circ} \mathrm{C}$ (Collins 1977).

Prevailing low temperatures throughout the Antarctic biome are generally considered to limit net photosynthesis $\left(\mathrm{P}_{\mathrm{n}}\right)$ for most of the growing season (Xiong et al. 1999). However photosynthetic organs can reach relatively high temperatures and show much greater fluctuations than seen in diurnal air temperature, eg $+20^{\circ} \mathrm{C}$ above ambient on the continent (Longton 1974, Melick and Seppelt 1994b). In contrast, in the subantarctic plant Pringlea antiscorbutica at Iles Kerguelen, leaf temperature is maintained far lower than maximum air temperature $\left(23^{\circ} \mathrm{C}\right)$ on warm days, possibly through the intense leaf transpiration observed (Aubert et al. 1999a). Increased $P_{n}$ under elevated temperature has been demonstrated in three continental moss species (Smith 1999) and the two maritime vascular species (Xiong et al. 2000) whilst in contrast, decreases in $\mathrm{P}_{\mathrm{n}}$ were observed in other mosses and vascular plants (Vining et al. 1997, Xiong et al. 1999). In many species, increasing temperatures can reduce carbon gain by increasing respiratory loss (Nakatsubo 2002). Decreases in $P_{n}$ under increasing temperatures might also be due to consequential increase in photoinhibition as has been shown in some continental Antarctic mosses (Kappen et al. 1989).

The relative importance of temperature and irradiance to photosynthetic rates varies. In the two maritime Antarctic vascular plants net photosynthetic rates are negligible at canopy air temperatures greater than $20{ }^{\circ} \mathrm{C}$, with temperature, rather than high irradiance responsible for this photosynthetic depression (Xiong et al. 1999). However, it has also been demonstrated for these species that increasing vegetative growth outweighs decreases in photosynthetic rates under $20{ }^{\circ} \mathrm{C}$ daytime temperatures (Xiong et al. 2000). In subantarctic species such as the crucifer Pringlea antiscorbutica and the grass Poa cookii, net photosynthesis is very little affected by temperature within a range of naturally occurring values $\left(2.5-25^{\circ} \mathrm{C}\right)$ and is much more responsive to irradiance (Bate and Smith 1983, Aubert et al. 1999a).

\section{DEVELOPMENTAL AND METABOLIC RESPONSES}

While Antarctic plants are, generally speaking, at their biological limits for sexual reproduction, diverse patterns are found. The two antarctic flowering plants, Colobanthus quitensis (Kunth) Bartl. and Deschampsia antarctica Desv., although flowering every year down to the southern limits of their distribution, do not always 
achieve mature seed and their reproductive performance appears to be linked with habitat favourability (Edwards 1974). In contrast, several autochthonous subantarctic plants, including endemic species from the Kerguelen phytogeographical province, show a regular and relatively high production of viable seeds and share rapid development and early seed ripening (Dorne 1977, Hennion and Walton 1997a,b, Chapuis et al. 2000). Other autochthonous, non-endemic species encounter limitations in seed fertility due to embryo immaturity or dormancy, which are also reported in their more northerly locations but are more severe in subantarctic sites and reproductive capacity of these species may be influenced by site favourability (Walton 1976, Dorne 1977, Hennion and Walton 1997a,b). In Macquarie Island, with a milder climate, diverse patterns of phenology and seed fertility are found (Bergstrom et al. 1997). Finally, while the majority of species alien to the subantarctic do not achieve successful sexual reproduction, a minority show high production of viable seeds and have become invasive (Frenot et al. 2005).

Autochthonous subantarctic plants and the two antarctic phanerogams have high temperature optima for germination $\left(\mathrm{c} .20^{\circ} \mathrm{C}\right.$ ) as is also observed in arctic and alpine species, a feature possibly related to high soil surface temperatures during the summer (Holtom and Greene 1967, Callaghan and Lewis 1971, Dorne 1977, Hennion and Walton 1997a,b). Meanwhile, rates of germination at low temperatures are greatly improved by cold pretreatment (Holtom and Greene 1967, Dorne 1977, Walton 1977, Frenot and Gloaguen 1994, Hennion and Walton 1997a), with longterm cold storage of soil cores from the west Antarctic Peninsula promoting increased germination rates from seed banks (Ruhland and Day 2001). This suggests that enhanced temperature under climate change may, firstly, increase the germination rate of autochthonous subantarctic and Antarctic species. However, changes in temperature and water availability are also expected to affect seed output and fertility and seedling survival, making the combined consequences of climate change on the colonisation success of individual species hard to predict. Along the Antarctic Peninsula, increases in both the size and number of populations of $D$. antarctica and $C$. quitensis over the last 20 years and the frequency of successful seed maturation suggest that longer, warmer and wetter growing seasons have a positive effect on their reproductive capacity (Convey 1996a, Day et al. 1999). Thus, evaluating the impacts of climate variables on the reproductive success of autochthonous and alien phanerogams should be one of the key targets for plant ecophysiologists in the subantarctic and Antarctic.

Amongst autochthonous species, the crucifer Pringlea antiscorbutica, a highly successful plant of the Iles Kerguelen and Iles Crozet, Marion and Heard Islands, displays several features indicating specific adaptation to subantarctic climate. On Iles Kerguelen, P. antiscorbutica is found from the shore to the highest vegetated areas, and is tolerant to chilling, frequent freeze-thaw cycles and some salt exposure (Hennion and Bouchereau 1998). In contrast, all attempts to cultivate the Kerguelen cabbage under temperate conditions have failed, resulting in leaf necrosis, 
accelerated abscission and death after a few weeks (Dorne 1981, Hennion and Martin-Tanguy 2000). The sensitivity of seedling, especially root, development to high temperature appears as soon as germination is completed (Dufeu et al. 2003, Hummel et al. 2004a) (Fig. 3). Polyamines, growth regulators involved in stress response and reported at high levels in some cold tolerant plants, are abundant in Pringlea antiscorbutica and also in Lyallia kerguelensis, a species endemic to Iles Kerguelen (Hennion and Martin-Tanguy 1999, 2000). The level of agmatine is positively correlated with the root growth rate of $P$. antiscorbutica seedlings at low temperature (Hummel et al. 2002). The balance of polyamine metabolism is dramatically affected by heat stress in both seedlings and mature plants, with for instance accumulations of putrescine or spermidine possibly due to depressed catabolism (Hennion and Martin-Tanguy 2000, Dufeu et al. 2003, Hummel et al. 2004a). Additionally, the aromatic amines dopamine and tyramine are present at high levels in this species and are strongly responsive to heat stress (Hennion and Martin-Tanguy 2000, Dufeu et al. 2003). These developmental and metabolic characteristics indicate a particular sensitivity of $P$. antiscorbutica to enhanced temperatures at all stages and suggest that this and other autochthonous subantarctic species may not have the physiological flexibility to cope with large increases in temperature. Little is known about the metabolic responses of antarctic plants to increased temperature.
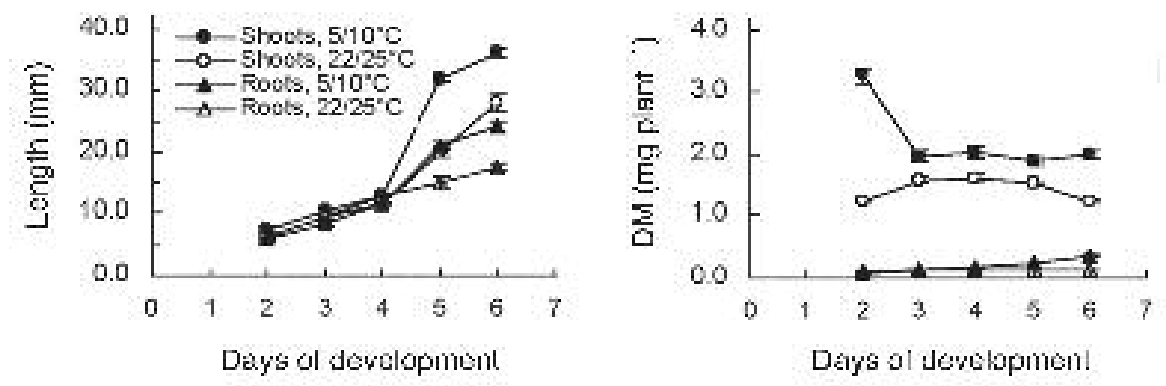

Figure 3. Changes in growth parameters (length and dry mass) during seedling development of Kerguelen cabbage, Pringlea antiscorbutica $R$. Br., under $a 5^{\circ} \mathrm{C} / 10^{\circ} \mathrm{C}$ night/day (closed symbols) or a $22^{\circ} \mathrm{C} / 25^{\circ} \mathrm{C}$ night/day (open symbols) regime. Day 0 is the time of radicle emergence, post-germination lasts until day 2 (Adapted from Dufeu et al. 2003).

Some other biochemical features of Antarctic plants are also significant. The subantarctic $P$. antiscorbutica and maritime Antarctic Deschampsia antarctica display high levels of soluble carbohydrates, likely to be important in cryoprotection in addition to tolerance of desiccation and freeze-thaw events (Hennion and Bouchereau 1998, Aubert et al. 1999a, Zuñiga et al. 1996). The two maritime Antarctic vascular plants show different cold tolerance strategies. Deschampsia 
antarctica is freezing tolerant, with a low $\mathrm{LT}_{50}$ temperature, whereas Colobanthus quitensis is freeze avoiding (Alberdi et al. 2002). Reyes et al. (2003) suggested that heat shock protein (HSP70) accumulation may protect $D$. antarctica against temperatures lower or higher than its optimal photosynthetic temperature, a role reported for these proteins in several other species. Neither $D$. antarctica nor $P$. antiscorbutica has a lipid composition characteristic of cold resistant plants either in the content of polar lipids or the degree of unsaturation of fatty acids, a finding possibly related to the temperatures of leaves often being higher than air temperature in the sub- and maritime Antarctic (Dorne et al. 1987, Zuñiga et al. 1994).

\section{Antarctic plants under changing water availability}

\section{WATER}

On the Antarctic continent most water is permanently locked up as ice and snow, while large areas are accurately described as frigid desert, receiving very low or no direct precipitation and experiencing chronically low relative humidity. Organisms living here must therefore be able to survive long periods of freezing and consequent drought, year round. In the summer, water may become available from snowmelt and around melt lakes, however, this water supply is transient and repeated freezethaw events still occur. In the maritime and subantarctic, water is less limiting, although the maritime region experiences extended periods of freezing during winter and rainfall plays a more important role. Throughout the region water availability thus varies spatially and temporally, with large variation occurring from year to year. At a broad scale, levels of tolerance of desiccation therefore vary across the Antarctic biome and among species, with the maritime region supporting some desiccation-sensitive species, particularly in hydric habitats (Davey 1997a,b,c, Robinson et al. 2000, Lange and Kappen 1972).

On the continent, all water comes from melted snow. Uptake of water by lichens is largely from snow deposited on their surfaces which, even at subzero temperatures, can be adequate for rehydration (Kappen and Breuer 1991, Kappen 1993, 2000, Schroeter et al. 1994, 1997, Schroeter and Scheidegger 1995, Pannewitz et al. 2003). These lichens show extraordinarily high levels of tolerance of desiccation and are capable of reactivating photosynthetic activity very rapidly via uptake of water vapour (Lange and Kappen 1972, Hovenden et al. 1994, Hovenden and Seppelt 1995). Although lichens can receive sufficient light to photosynthesise under several centimetres of snow (Lange and Kappen 1972, Walton 1982), the insulating effects of snow cover may normally maintain temperatures below the minimum for photosynthesis (Pannewitz et al. 2003).

Continental Antarctic bryophytes, whilst less tolerant of increasing aridity than lichens, also have the ability to survive desiccation. Species-specific differences in tolerance of desiccation have been detected for three moss species from the 
Windmill Islands, East Antarctica (Robinson et al. 2000, Wasley et al. 2006b), with two cosmopolitan species (Bryum pseudotriquetrum, Ceratodon purpureus) able to metabolise at lower turf water content than the endemic Grimmia antarctici $\approx$ Shistidium antarctici. Bryum pseudotriquetrum also shows greater plasticity than the other species, with plants from drier sites showing greater tolerance of desiccation that those from wetter sites, in addition to seasonal changes in desiccation tolerance (Robinson et al. 2000, Wasley et al. 2006b). The ability to survive repeated desiccation and freezing events is probably related to the high concentrations of soluble carbohydrates found in these species (Melick and Seppelt 1994b) and in particular the presence of compounds such as stachyose and trehalose in $B$. pseudotriquetrum (Robinson et al. 2000, Wasley et al. 2006b). In contrast $C$. purpureus has a much higher proportion of fatty acids/soluble carbohydrates. All three species have a high proportion of their fatty acids in polyunsaturated forms (> 67\%), a feature characteristic of cold tolerant higher plants (Zuñiga et al. 1996, Wasley et al. 2006b). Quantifying the relative importance of lipids versus soluble carbohydrates in these freeze tolerant plants stands out as an interesting target for further study, it may be that lipids are a safer storage compound, since soluble carbohydrates are known to leak from bryophytes during desiccation-rehydration and freeze thaw cycles (Melick and Seppelt 1992).

In general, the evidence suggests that net photosynthesis and growth are currently limited by water availability (Fowbert 1996, Davey 1997a,b,c, Schlensog and Schroeter 2000). However this may not be the case for lichens, where high water content can cause a depression of net photosynthesis (Kappen and Breuer 1991, Hovenden et al. 1994, Pannewitz et al. 2003). Antarctic bryophytes sampled from wetter sites have higher water contents at full hydration (Robinson et al. 2000), chlorophyll concentrations (Kappen et al. 1989, Melick and Seppelt 1994a), concentrations of soluble carbohydrates (Melick and Seppelt 1994a, Robinson et al. 2000), nitrogen and potassium (Fabiszewski and Wojtun 2000), turf $\mathrm{CO}_{2}$ concentrations (Tarnawski et al. 1992), rates of nitrogen fixation (Davey 1982, Davey and Marchant 1983) and production rates, in addition to a wider temperature range for maximal net photosynthesis (Kappen et al. 1989). On the negative side, photosynthetic efficiency decreases at higher tissue water contents (Robinson et al. 2000) and tissues freeze at higher temperatures (Melick and Seppelt 1994a) in samples collected from wet sites compared to those from dry sites. For lichens, increased water availability may decrease photosynthesis and appears to have a destabilizing effect on the symbiotic relationship, with the free-living algal and intermediate forms becoming more dominant in wet habitats (Huiskes et al. 1997).

Water is less likely to be limiting in the relatively moist maritime Antarctic. On Signy Island, whilst some xeric species are occasionally water-limited (Davey 1997c), more generally photosynthesis is not water-limited (Collins 1977). When the photosynthetic rates of a range of xeric and hydric species from this island were compared under laboratory conditions, no difference among habitats was detected 
(Convey 1994). Maritime moss species from a variety of habitats (hydric, mesic, xeric) also experience increased penetration of light into the turf as drying occurs, counteracting at least in the short term the loss of productivity during periods of desiccation (Davey and Rothery 1996).

Subantarctic climates are generally described as having a strong maritime influence, with high levels of precipitation. Over recent decades, however, climate change data are becoming available from this region that, in some locations, indicate a dramatic reduction in precipitation (Bergstrom and Chown 1999). Newly experienced drought periods visibly affect autochthonous subantarctic species. Among these, Pringlea antiscorbutica displays several features indicative of sensitivity to water stress, such as permanently high leaf relative water content despite a low leaf diffusion resistance and stomatal closure only under severe water deprivation, all facts in accordance with this species growing exclusively in places with water-saturated soils (Dorne and Bligny 1993). Mature P. antiscorbutica plants show some salt tolerance with characteristics such as high levels of proline in all organs and proline accumulation in the cell cytoplasm in response to salt concentration in the surrounding medium (Hennion and Bouchereau 1998, Aubert et al. 1999a,b). In contrast, in field microenvironments as under laboratory experiments, water and salt stresses were shown to result in a drastic reduction of root growth and high mortality of seedlings, suggesting that seedling establishment of $P$. antiscorbutica may be restricted by climate change (Hummel et al. 2004b).

Water availability has been shown to influence turf and gametophyte morphology in a range of continental and maritime Antarctic mosses and this, in turn, can affect water relations (Nakanishi 1979). In general, gametophyte shoots are shorter and turf denser in drier sites (Gimingham and Smith 1971, Wilson 1990, Wasley 2004, Wasley et al. 2006b). Indeed, the changes in plant morphology and growth patterns that are reported as the norm in many long-term environmental manipulation experiments, often implicitly assumed to relate primarily to temperature increase, may equally well be explained by changes in microclimate humidity and soil moisture. Some subantarctic higher plants, such as the magellanic Ranunculus biternatus and $R$. pseudotrullifolius and the Kerguelen endemic $R$. moseleyi, three closely related species (Hennion and Couderc 1992, 1993), show high variability of leaf morphology in relation with environmental water availability (Hennion et al. 1994). R. pseudotrullifolius and $R$. moseleyi were characterized by developmental flexibility which increased the degree of heterophylly in fluctuating conditions, which could be considered adaptive to the wide variations of water level in their aquatic habitats. In contrast, $R$. biternatus had a much wider variability in leaf shape, part of which could be genetically fixed, and which could be related with the more varied, terrestrial habitats of this species (Hennion et al. 1994). As a whole, data suggest that $R$. biternatus may be better fitted to cope with present climate drying at Iles Kerguelen than the more biogeographically and ecologically restricted $R$. pseudotrullifolius and $R$. moseleyi.

In the subantarctic, altitudinal factors strongly influence the frequency of freeze- 
thaw events experienced by biota. For example, $P$. antiscorbutica grows at a range of altitudes and can experience frequent freeze-thaw cycles (Hennion and Bouchereau 1998). High levels of glucose present in the leaves of this species may help in protection against osmotic stresses (Hennion and Bouchereau 1998), such as that experienced in association with ice formation. In general, continental Antarctic plants can survive repeated freeze-thaw events (Melick and Seppelt 1992), whilst maritime species appear to be less tolerant (Davey 1997b). The pattern of exposure to freezing is also important - repeated freeze-thaw cycles cause a greater reduction in gross photosynthesis than constant freezing over the same time period (Kennedy 1993). Tolerance of freeze-thaw events involves interactions with other environmental parameters, in particular that of water availability. For example, desiccation before freezing reduces damage to the photosynthetic apparatus, while protection from freeze-thaw events can be provided by snow cover acting as an insulator (Lovelock et al. 1995a,b). Ice nucleation activity, measured on 19 species of lichens, mosses and flowering plants, ranked in the order: lichens > mosses > flowering plants (Worland et al. 1996). In the search for genes associated with freezing tolerance, cold-acclimation related transcripts were isolated from Deschampsia antarctica and appeared also responsive to water stress (Gidekel et al. 2003).

\section{NUTRIENTS}

Nutrient cycling in the Antarctic is relatively slow, due to the constraints imposed on biological activity by low temperatures and extreme aridity. Nutrient availability in Antarctic terrestrial ecosystems is patchy, with high concentration of nutrients in the vicinity of bird and seal colonies, whilst elsewhere nutrients are limited to those deposited in precipitation and through aerosol transfer from the sea (Allen et al. 1967, Greenfield 1992a,b). Nutrient requirements for Antarctic vegetation have been reported to be so low that nitrogen levels in precipitation were assumed to be nonlimiting for growth of cryptogams, particularly lichens (Greenfield 1992a, Crittenden 1998). However, nutrient availability does play a role in determining patterns of species distributions in Antarctica. Two studies, in particular, have demonstrated positive correlations between vegetation patterns and nutrient availability associated with nutrient inputs from birds (Gremmen et al. 1994, Leishman and Wild 2001). A recent field manipulation study has shown that, in both moss and lichen communities, electron transport rate and chlorophyll content respond positively to nutrient inputs (Wasley et al. 2006a), suggesting that nutrient limitations may be more important than previously thought (Beyer et al. 2000). This finding is particularly relevant in the context of future climate scenarios, since plants may be unable to respond to changes in thermal climate or hydration if nutrients become limiting.

In the continental and maritime Antarctic, release of nutrients from organic 
matter is primarily mediated through microbial processes and is relatively slow (Smith and Steenkamp 1992). In contrast, in the subantarctic, rates of inorganic nutrient release from plant litter are enhanced by macro-invertebrate communities (Smith and Steenkamp 1992) which are absent on the continent. Smith (2005) used a modelling approach to examine decomposition-related phenomena in the subantarctic across a broad range of soils from Marion Island. Respiration rate was shown to increase with soil moisture content and the degree of this response strongly increased with temperature, especially above $10^{\circ} \mathrm{C}$. The model predicted that the currently experienced drying of soils, due to climate drying, on Marion would result in a decrease in soil respiration rate, despite a slight positive effect of warming. In addition, the consequences of nutrient input from vertebrates were shown to include improved primary production, larger, more active and more diverse soil microbial populations and larger populations of microbivores (Smith 2005).

Increased nutrient availability is not automatically an advantage to Antarctic biota. In the extreme, this is obvious in the context of such events as excessive manuring by vertebrates such as Antarctic fur seals causing the death of moss banks (Smith 1988), an effect that is separate to but generally acts in concert with physical trampling. Some Antarctic plants, such as Pringlea antiscorbutica seedlings, display strikingly better growth under nutrient deprivation than addition (Hummel et al. 2004a), a feature which may apply more generally than currently thought in species characteristic of oligotrophic habitats. Recent studies have demonstrated mycorrhizae to be associated with several subantarctic plant species, with variable plant mycorrhizal status among sites, some data suggested that mycorrhizae might be involved in plant colonization in oligotrophic sites (Strullu et al. 1999). The sensitivity of this symbiotic association to climate change processes is unknown. Finally, as climate change is also likely to alter patterns of rock weathering and release of elements, impacts of changes in nutrient supply are to be expected on the physiological performances of plants.

\section{Invertebrates under changes in temperature and water patterns}

A range of ecophysiological studies support there being a very close relationship, both over short-term and evolutionary timescales, between tolerance of desiccation and cold (Ring and Danks 1994, Block 1996, Worland 1996, Worland et al. 1998). Ecophysiological and biochemical features associated with cold tolerance have received much attention (see Zachariassen 1985, Block 1990, Duman et al. 1991, Lee and Denlinger 1991, Wharton 1995, Danks 1996, Sinclair et al. 2003a,b, while Cannon and Block 1988, Danks et al. 1994 and Convey 1996b apply to polar studies), with cold tolerance strategies now being grouped into ecologically-useful classifications (Bale 1993, Sinclair 1999).

Freezing tolerant organisms (those that can survive the formation of ice within their body, normally in extracellular spaces) can 'seed' ice formation at relatively 
high sub-zero temperatures by using ice nucleators such as specific proteins or bacteria. Control of the process of ice formation, which is more easily achievable at higher sub-zero temperatures, appears to be key to organism survival here. As temperature decreases further after initial ice formation there is much variation among taxa in the degree of protection provided, with some only surviving a few degrees below the freezing point while others can then tolerate biologically unrealistic extreme low temperatures. Freezing susceptible organisms (that die when ice forms within their body) can lower their freezing point and stabilise the supercooled state by the use of a range of cryoprotectant chemicals, including antifreezes, polyhydric alcohols and sugars, and antifreeze proteins.

Most Antarctic arthropods are freezing susceptible and have been key in the study of supercooling (Fig. 4). Freezing tolerant species of higher insect are also present, including Diptera, Coleoptera and Lepidoptera. Application of the various cold tolerance classification systems starts to break down when applied to the groups of smaller soil invertebrates that progressively assume dominance in more extreme Antarctic terrestrial habitats, including tardigrades, nematodes and rotifers. When these experience freezing immersed in water (such as would coat soil particles or vegetation) at high sub-zero temperatures, they cannot resist ice nucleation from their surroundings and can show considerable levels of freeze tolerance (Wharton 1995, Wharton and Block 1993, 1997, Convey and Worland 2000a). A similar process occurs in 'frost hardy' plants. However, when the same species are exposed to classical experimental supercooling methodologies, they can respond as freezing susceptible species, showing considerable supercooling ability but dying at the freezing point (Convey and Worland 2000b). Finally, many representatives of these groups, which typically have very little resistance to water loss, have well-developed ability to survive desiccation, showing particular development of the process of anhydrobiosis (Pickup and Rothery 1991, Wharton 1995).

The parallels between processes allowing tolerance of freezing and desiccation are well illustrated by consideration of events at the cellular level. Both involve the protection of cell membranes and organelles. The formation of ice crystals in extracellular spaces draws water out of cells by osmosis, in an analogous process to that experienced during desiccation. In both cases, cryoprotectants such as trehalose allow stabilisation of membranes and soluble proteins (Ring and Danks 1994, Block 1996). Some nematodes appear to have taken this ability one step further, and are able to survive intracellular freezing (Wharton 1995, Wharton and Ferns 1995), an ability previously thought to be restricted to certain isolated invertebrate tissues and not whole organisms. A frozen organism has no ability to actively control further water loss (Worland 1996, Worland et al. 1998). If in contact with air, water loss will inevitably continue to take place, ultimately resulting in freeze-drying. In addition to the invertebrate groups mentioned, many elements of the flora of Antarctic ecosystems are well adapted to tolerate such desiccation processes, often repeatedly over relatively short timescales, being poikilohydrous (Green et al. 1999, 
Kappen and Valladares 1999).

All the ecophysiological tactics of permitting cold or desiccation tolerance referred to above involve significant physiological costs, which must reduce the finite reserves of an organism that can be made available for other activities. While there are few estimates available, it is clear that costs may be considerable (eg Green et al. 1999). Circumstantial evidence in support of a 'trade-off' between investment in stress tolerance and another ecologically important function (reproduction) is provided by a study of reproductive investment of an antarctic Oribatid mite across the natural environmental gradient between South Georgia and Marguerite Bay (c. $54-69^{\circ} \mathrm{S}$ ) (Convey 1998). This found significantly greater investment in reproduction in the milder subantarctic location. Given the considerable costs involved in stress protection tactics, there is clearly likely to be a selective advantage associated with their efficient use. Thus, while variation over seasonal timescales in abilities such as cold tolerance is well known (Cannon and Block 1988, Block 1990), it is only recently that attention has been given to more rapid dynamic or responsive changes in levels of stress protection which might allow invertebrates to take maximum advantage of the opportunities provided for feeding and growth during the short austral summer season (Convey and Worland 2000b, Worland and Convey 2001, Sinclair et al. 2003c). Alternatively, in the subantarctic where thermal buffering of summer microclimate is experienced through the strong maritime influence (Convey 1996c, Danks 1999), there is reduced need to invest resources in cold survival. In the most extreme terrestrial habitats of the continental Antarctic the reverse is seen, with high levels of cold tolerance required year-round (Sømme 1986), as there is no time of the year in which freezing events are not experienced.

Antarctic terrestrial invertebrates clearly possess the features required to allow survival of the environmental stresses experienced, although few of these can be claimed to be 'true' or evolutionary adaptations and they are generally considered to be ancestral features (Norton 1994, Convey 1996b, 1997). However, it is clear that 'whole-body processes' such as growth, feeding, movement and survival, which effectively integrate the many biochemical and physiological processes occurring within the body, often have low temperature optima, which indicates the presence of adaptation even though the detail is not known (eg Marshall et al. 1995, Convey 1996b). There continues to be considerable debate over the existence or functional importance of metabolic rate elevation at low temperatures (Block 1990, Clarke 1991, 1993, Chown and Gaston 1999, Addo-Bediako et al. 2002). Although this feature has been reported in several studies of terrestrial arthropods, along with the related feature of lowered enzyme activation energies, there remain significant doubts over methodological validity or data interpretation.

Antarctic terrestrial habitats experience high natural variability in environmental stresses, with the magnitude of these variations generally far outweighing those that are linked with climate change. Therefore, as a broad generalisation, it is predicted that Antarctic terrestrial invertebrates, and their communities, are likely to benefit from current change trends (Convey 2003). They are likely to experience reduced 
levels of environmental stress (and hence levels of investment required to counter these stresses), greater access to resources and longer active seasons over which to develop. Indeed, it is expected that Antarctic (and Arctic) species generally will show particular sensitivity and strength of response, at least to warming: as they currently spend long periods operating near to lower thermal and other limits for activity, small increases will have a relatively much greater significance than similar increases from a higher baseline (Kennedy 1994, Strathdee et al. 1995, Freckman and Virginia 1997, Arnold and Convey 1998, Convey 2003).

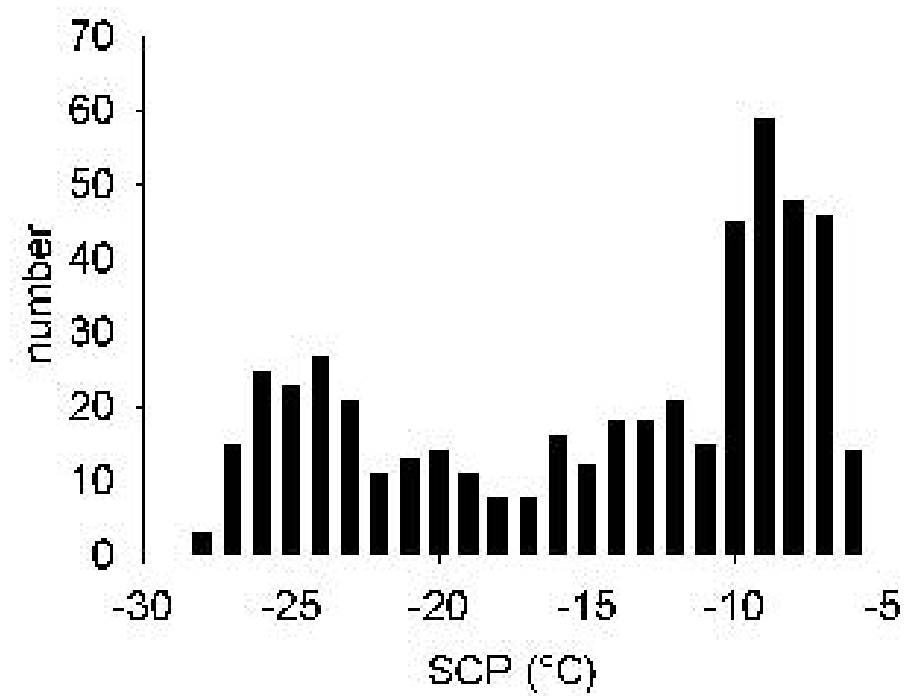

Figure 4. Typical bimodal distribution of supercooling (individual freezing) points in a natural population of the freezing-susceptible springtail, Cryptopygus antarcticus, these two groups are formed by individuals either having relatively high sub-zero freezing points, and limited cold tolerance ability, or relatively low sub-zero freezing points and very high cold tolerance (data supplied by M.R. Worland).

However, many interacting variables influence the biology of these invertebrates and it is clear that some circumstances can restrict the activity and distribution of some biota. Thus, the key role of water availability has been recognised (Kennedy 1993) and it is clear that some regions of the Antarctic will experience decreased precipitation and increased drought stress. Some terrestrial invertebrates, such as Collembola, while responding positively to temperature increase, are also particularly sensitive indicators of water stress and changes are likely to result in altered limits to distribution (Block and Harrisson 1995, Block and Convey 2001, 
Convey et al. 2003a).

In particular circumstances, it is also possible that species distributions could be limited as maximum microhabitat temperatures approach upper thermal limits. Unlike the ability shown by many invertebrates (not only polar species) to acclimate or acclimatise to low temperatures, upper thermal limits appear to show less flexibility (Addo-Bediako et al. 2000) and, thus, any increase in time spent near these temperatures may be costly. The potential importance of upper thermal limits in biological responses to climate change has been raised in a study of subantarctic weevils (Coleoptera) (van der Merwe et al. 1997).

\section{Conclusions}

Both observation and knowledge of the physiological characteristics of some antarctic organisms suggest that even the slight increase in temperature currently recorded in this region can significantly affect the organisms living there. This is also true for the expected or already observed changes in water availability. Physiological flexibility is a key factor in the ability of biota to cope with environmental change, whether caused through natural variability or anthropogenic change processes. Apparently small changes in processes (eg the limited photosynthetic response to a slight increase in mean temperature) may assume much greater significance in the context of pre-existing limitations on physiological activity in Antarctic habitats. Other metabolic processes having impacts on development, growth or reproduction may be much more sensitive to changes in environmental parameters, with significant consequences on survival, establishment and colonisation of both indigenous and introduced species. Few data are available in these areas and there is an urgent need to integrate specific studies of physiological processes at the whole organism and food web levels. Studies of physiological plasticity, linked with estimates of available genetic variability are also urgently required to assess accurately the impacts of climate change on the sensitive Antarctic terrestrial ecosystem.

As a broad generalization, maritime Antarctic biota are likely to be able to take advantage of predicted levels of environmental change, although the alternative possibility of increased limitation in specific circumstances must be recognised too. In contrast, current evidence suggests that subantarctic biota may be considerably more vulnerable. The relative importance of changes in different environmental variables (particularly thermal vs. precipitation) still needs to be assessed. At present, the great isolation of Antarctica from sources of colonizing biota acts to protect most indigenous species from the confounding effects of competition. However, the dangers of invasive species are already amply illustrated on some of the subantarctic islands, where human activity has led to the establishment of a range of vertebrates, invertebrates and plants (Frenot et al. 2005). Indigenous species are generally poor competitors (Convey 1996b) and it is far from clear how they will 
respond to the twin challenges presented by both climate change and alien colonization.

Finally, it is important to emphasise that studies of climate change responses need to incorporate not only individual target species, but also the possibility of interaction or synergistic links among environmental variables, and the cumulative consequences, when integrated through the food web, of apparently insignificant changes (Day 2001, Searles et al. 2001, Convey et al. 2002, Convey 2003).

\section{References}

Adamson, H. and Adamson, E. (1992) Possible effects of climate change on Antarctic terrestrial vegetation, in P. Quilty (ed.), Impact of Climate Change on Antarctica-Australia, Australian Government Publishing Service, Canberra, Australia, pp. 52-61.

Addo-Bediako, A., Chown, S.L. and Gaston, K.J. (2000) Thermal tolerance, climatic variability and latitude, Proceedings of the Royal Society of London, series B 267, 739-745.

Addo-Bediako, A., Chown, S.L. and Gaston, K.J. (2002) Metabolic cold adaptation in insects: a large scale perspective, Functional Ecology 16, 332338.

Alberdi, M., Bravo, L.A., Gutiérrez, A., Gidekel, M. and Corcuera, L.J. (2002) Ecophysiology of Antarctic vascular plants, Physiologia Plantarum 115, 479486.

Allen S.E., Grimshaw H.M. and Holdgate M.W. (1967) Factors affecting the availability of plant nutrients on an antarctic island, Journal of Ecology 55, 381-396.

Arnold, R.J. and Convey, P. (1998) The life history of the diving beetle, Lancetes angusticollis (Curtis) (Coleoptera: Dytiscidae), on subantarctic South Georgia, Polar Biology 20, 153160.

Aubert, S. Assard, N., Boutin, J.P., Frenot, Y. and Dorne, A.J. (1999a) Carbon metabolism in the subantarctic Kerguelen cabbage Pringlea antiscorbutica R. Br.: environmental controls over carbohydrates contents and relation to phenology, Plant, Cell and Environment 22, 243254.

Aubert, S., Hennion, F., Bouchereau, A., Gout, E., Bligny, R. and Dorne, A.J. (1999b) Subcellular compartmentation of proline in the leaves of the subantarctic Kerguelen cabbage Pringlea antiscorbutica $\mathrm{R}$. Br. In vivo 13C-NMR study, Plant, Cell and Environment 22, 255260.

Bale, J.S. (1993) Classes of insect cold hardiness, Functional Ecology 7, 751753.

Balo, K. (1967) Some photosynthesis-ecological characteristics of forest bryophytes, Symposia Biologica Hungarica 35, 125135

Barsig, M., Schneider, K. and Gehrke C. (1998) Effects of UV-B radiation on fine-structure, carbohydrates, and pigments in Polytrichum commune, Bryologist 101, 357-365.

Bate, G.C. and Smith, V.R. (1983) Photosynthesis and respiration in the subantarctic tussock grass Poa cookii, New Phytologist 95, 533-543.

Beggs, C.J. and Wellmann, E. (1994) Photocontrol of flavonoid biosynthesis, in R.E. Kendrick and G.H.M. Kronenberg (eds.), Photomorphogenesis in Plants, Kluwer Academic Publishers, Dordrecht, The Netherlands, pp 733-751.

Bergstrom, D.M., Selkirk, P.M., Keenan, H.M. and Wilson, M.E. (1997) Reproductive behaviour of ten flowering plant species on subantarctic Macquarie Island, Opera Botanica 132: 109-132.

Bergstrom, D.M. and Chown, S.L. (1999) Life at the front: history, ecology and change on southern ocean islands, Trends in Ecology and Evolution 14, 472477.

Beyer, L., Bolter, M. and Seppelt, R.D. (2000) Nutrient and thermal regime, microbial biomass, and vegetation of Antarctic soils in the Windmill Islands region of east Antarctica (Wilkes Land), Arctic, Antarctic and Alpine Research 32, 30-39.

Block, W. (1990) Cold tolerance of insects and other arthropods, Philosophical Transactions of the Royal Society of London Series B 326, 613-633.

Block, W. (1996) Cold or drought - the lesser of two evils for terrestrial arthropods? European Journal of 
Entomology 93, 325339.

Block, W. and Convey, P. (2001) Seasonal and long-term variation in body water content of an Antarctic springtail - a response to climate change? Polar Biology 24, 764770.

Block, W. and Harrisson, P.M. (1995) Collembolan water relations and environmental change in the maritime Antarctic, Global Change Biology 1, 347359.

Bornman, J.F. and Sundby-Emanuelsson, C. (1995) Response of plants to UV-B radiation: some biochemical and physiological effects, in N. Smirnoff (ed.), Environment and plant metabolism, Bios Scientific Publishers, Oxford, U.K., pp. 245-262.

Buma, A.J.G., van Hannen, E.J., Roza, L., Veldhuis, M.J.W. and Gieskes, W.W.C. (1995) Monitoring Ultraviolet-B induced damage in individual diatom cells by immunofluorescent thymine dimer detection, Journal of Phycology 31, 314321.

Buma, A.G.J., De Boer, M.K. and Boelen, P. (2001) Depth distributions of DNA damage in Antarctic marine phyto- and bacterioplankton exposed to summertime ultraviolet radiation. Journal of Phycology 37, 200208.

Callaghan, T.V. and Lewis, M.C. (1971) Adaptation in the reproductive performance of Phleum alpinum L. at a subantarctic station, British Antarctic Survey Bulletin 26, 59-75.

Cannon, R.J.C. and Block, W. (1988) Cold tolerance of microarthropods, Biological Reviews 63, 23-77.

Chapuis, J.L., Hennion, F., Le Roux, V. and Le Cuziat, J. (2000) Growth and reproduction of the endemic cruciferous species Pringlea antiscorbutica in Kerguelen Islands, Polar Biology 23, 196204.

Chown, S.L. and Gaston, K.J. (1999) Exploring links between physiology and ecology at macro-scales: the role of respiratory metabolism in insects, Biological Reviews 74, 87-120.

Clarke, A. (1991) What is cold adaptation and how should we measure it? American Zoologist 31, 81-92.

Clarke, A. (1993) Seasonal acclimatisation and latitudinal compensation in metabolism: do they exist? Functional Ecology 7, 139149.

Cockell, C.S., Rettberg, P., Horneck, G., Wynn-Williams, D.D., Scherer, K. and Gugg-Helminger, A. (2002) Influence of ice and snow covers on the UV exposure of terrestrial microbial communities: dosimetric studies, Journal of Photochemistry and Photobiology, B-Biology 68, 23-32.

Collins, N.J. (1977) The growth of mosses in two contrasting communities in the maritime Antarctic: measurement and prediction of net annual production, in G.A. Llano (ed.), Adaptations within Antarctic ecosystems, Gulf Publishing, Houston, Texas, pp. 921-933.

Convey, P. (1994) Photosynthesis and dark respiration in Antarctic mosses - an initial comparative study, Polar Biology 14, 65-69.

Convey, P. (1996a) Reproduction of Antarctic flowering plants, Antarctic Science 8, 127134

Convey, P. (1996b) The influence of environmental characteristics on life history attributes of Antarctic terrestrial biota, Biological Reviews 71, 191225.

Convey, P. (1996c) Overwintering strategies of terrestrial invertebrates from Antarctica - the significance of flexibility in extremely seasonal environments, European Journal of Entomology 93, 489-505.

Convey, P. (1997) How are the life history strategies of Antarctic terrestrial invertebrates influenced by extreme environmental conditions? Journal of Thermal Biology 22, 429-440.

Convey, P. (1998) Latitudinal variation in allocation to reproduction by the Antarctic oribatid mite, Alaskozetes antarcticus, Applied Soil Ecology 9, 93-99.

Convey, P. (2001) Terrestrial ecosystem response to climate changes in the Antarctic, in G.-R. Walther C.A. Burga and P.J. Edwards (eds.), "Fingerprints" of climate change - adapted behaviour and shifting species ranges, Kluwer, New York, pp 17-42.

Convey, P. (2003) Maritime Antarctic climate change: signals from terrestrial biology, in E. Domack, A Burnett, A. Leventer, P. Convey, M. Kirby and R. Bindschadler (eds.), Antarctic Peninsula Climate Variability: Historical and Palaeoenvironmental Perspectives, Antarctic Research Series, Vol. 79, American Geophysical Union, Washington, D.C., pp. 145-158.

Convey, P. (2006) Antarctic climate change and its influences on terrestrial ecosystems, in D.M. Bergstrom, P. Convey, and A.H.L. Huiskes (eds.), Trends in Antarctic Terrestrial and Limnetic Ecosystems: Antarctica as a Global Indicator. Springer, Dordrecht (this volume).

Convey, P. and Worland, M.R. (2000a) Survival of freezing by free-living Antarctic soil nematodes, Cryo Letters 21, 327-332.

Convey, P. and Worland, M.R. (2000b) Refining the risk of freezing mortality for Antarctic terrestrial 
microarthropods, Crye Letters 21, 333-338.

Convey, P., Pugh, P. J. A., Jackson, C., Murray, A. W., Ruhland, C. T., Xiong, F. S. and Day, T. A. (2002) Response of Antarctic terrestrial arthropods to multifactorial climate manipulation over a four year period. Ecology 83, 3130-3140.

Convey, P., Block, W. and Peat, H.J. (2003a) Soil arthropods as indicators of water stress in Antarctic terrestrial habitats? Global Change Biology 9, 1718-1730.

Convey, P., Scott, D. and Fraser, W.R. (2003b) Biophysical and habitat changes in response to climate alteration in the Arctic and Antarctic, in T.E. Lovejoy and L. Hannah (eds.), Climate Change and Biodiversity: Synergistic Impacts, International Conservation Center for Applied Biodiversity Science, Advances in Applied Biodioversity Science 4, pp. 79-84.

Crittenden, P.D. (1998) Nutrient exchange in an Antarctic macrolichen during summer snowfall snow melt events, New Phytologist 139, 697-707.

Danks, H.V. (1996) The wider integration of studies on insect cold-hardiness, European Journal of Entomology 93, 383403.

Danks, H.V. (1999) Life cycles in polar arthropods - flexible or programmed? European Journal of Entomology 96, 83-102.

Danks, H.V., Kukal, O. and Ring, R.A. (1994) Insect cold-hardiness: insights from the Arctic, Arctic 47, 391-404.

Davey, A. (1982) In situ determination of nitrogen fixation in Antarctica using a high sensitivity portable gas chromatograph, Australian Journal of Ecology 7, 395402.

Davey, M.C. (1997a) Effects of continuous and repeated dehydration on carbon fixation by bryophytes from the maritime Antarctic, Oecologia 110, 25-31.

Davey, M.C. (1997b) Effects of physical factors on photosynthesis by the Antarctic liverwort Marchantia berteroana, Polar Biology 17, 219-227.

Davey, M.C. (1997c) Effects of short-term dehydration and rehydration on photosynthesis and respiration by Antarctic bryophytes, Environmental and Experimental Botany 37, 187198.

Davey, A. and Marchant, H. (1983) Seasonal variation in nitrogen fixation in Nostoc commune Vaucher at the Vestfold Hills, Antarctica, Phycologia 22, 377385.

Davey, M.C. and Rothery, P. (1996) Seasonal variation in respiratory and photosynthetic parameters in three mosses from the maritime Antarctic, Annals of Botany 78, 719-728.

Day, T.A. (2001) Multiple trophic levels in UV-B assessments - completing the ecosystem, New Phytologist 152, 183186.

Day, T.A., Ruhland, C.T. and Xiong, F. (2001) Influence of solar UV-B radiation on Antarctic terrestrial plants: results from a 4-year field study, Journal of Photochemistry and Photobiology B: Biology 62, 78-87.

Day, T.A., Ruhland, C.T., Grobe, C.W. and Xiong, F. (1999) Growth and reproduction of Antarctic vascular plants in response to warming and UV radiation reductions in the field, Oecologia 119, 24 35.

Demmig-Adams, B. and Adams, W.W. (1992) Carotenoid composition in sun and shade leaves of plants with different life forms, Plant, Cell and Environment 15, 411-419.

Dorne, A.J. (1977) Analysis of the germination under laboratory and field conditions of seeds collected in the Kerguelen Archipelago, in G.A. Llano (ed.), Adaptations within Antarctic Ecosystems, 3rd SCAR Biology Symposium, Smithsonian, Washington DC, U.S.A., pp 1003-1013.

Dorne, AJ (1981) Etude du cycle végétatif et des premiers stades de croissance du Chou de Kerguelen, Pringlea antiscorbutica R.Br., Comité National Français pour les Recherches Antarctiques 48, 922.

Dorne, A.J. and Bligny, R. (1993) Physiological adaptation to subantarctic climate by the Kerguelen cabbage, Pringlea antiscorbutica R. Br., Polar Biology 13, 55-60.

Dorne, A.J. Joyard, J. and Douce, R. (1987) Lipid metabolism of a tertiary relic species, Kerguelen cabbage (Pringlea antiscorbutica), Canadian Journal of Botany 65, 2368-2372.

Dufeu, M., Martin-Tanguy, J. and Hennion, F. (2003) Temperature-dependent changes of amine levels during early seedling development of the cold-adapted subantarctic crucifer Pringlea antiscorbutica, Physiologia Plantarum 118, 164-172.

Duman, J.G., Wu, D.W., Xu, L., Tursman, D. and Olsen, M. (1991) Adaptations of insects to subzero 
temperatures, Quarterly Review of Biology 66, 387410.

Dunn, J. (2000) Seasonal variation in the pigment content of three species of Antarctic bryophytes, B.Sc.Adv.Honours Thesis, University of Wollongong, Australia.

Edwards, J.A. (1974) Studies in Colobanthus quitensis (Kunth) Bartl. and Deschampsia antarctica Desv.: VI. Reproductive performance on Signy Island, British Antarctic Survey Bulletin 39, 67-86.

Edwards, J.A. and Smith, R.I.L. (1988) Photosynthesis and respiration of Colobanthus quitensis and Deschampsia antarctica from the maritime Antarctic, British Antarctic Survey Bulletin 81, 43-63.

Fabiszewski, J. and Wojtun, B. (2000) Chemical composition of some dominating plants in the maritime antarctic tundra (King George Island), Bibliotheca Lichenologica 75, 79-91.

Fowbert, J.A. (1996) An experimental study of growth in relation to morphology and shoot water content in maritime Antarctic mosses, New Phytologist 133, 363373.

Freckman, D.W. and Virginia, R.A. (1997) Low-diversity Antarctic soil nematode communities: distribution and response to disturbance, Ecology 78, 363369.

Frenot, Y. and Gloaguen, J.-C. (1994) Reproductive performance of native and alien colonising phanerogams on a glacier foreland, Iles Kerguelen, Polar Biology 14, 473-481.

Frenot, Y., Chown, S.L., Whinam, J., Selkirk, P.M., Convey, P., Skotnicki, M. and Bergstrom, D.M. (2005) Biological invasions in the Antarctic: extent, impacts and implications, Biological Reviews 80 , 45-72.

Garcia-Pichel, F. and Castenholz, R.W. (1993) Occurrence of UV-absorbing Mycosporine-like compounds among cyanobacterial isolates and an estimate of their screening capacity, Applied Environmental Microbiology 59, 163-169.

Gehrke, C. (1998) Effects of enhanced UV-B radiation on production-related properties of a Sphagnum fuscum dominated subarctic bog, Functional Ecology 12, 940947.

Gidekel, M., Destefano-Beltran, L., Garcia, P., Mujica, L., Leal, P., Cuba, M., Fuentes, L., Bravo, L.A., Corcuera, L.J., Alberdi, M., Concha, I. and Gutiérrez, A. (2003) Identification and characterization of three novel cold acclimation-responsive genes from the extremophile hair grass Deschampsia antarctica Desv., Extremophiles 7, pp. 459-469.

George, A. L., Murray, A. W. and Montiel, P. O. (2001) Tolerance of Antarctic cyanobacterial mats to enhanced UV radiation, FEMS Microbiology Ecology 37, 91-101.

George, A. L., Peat, H. J. and Buma, A. G. J. (2002) Evaluation of DNA dosimetry to assess ozonemediated variability of biologically harmful ultraviolet radiation in Antarctica, Photochemistry and Photobiology 76, 274280.

Gimingham, C.H. and Smith, R.I.L. (1971) Growth forms and water relations of mosses in the maritime Antarctic, British Antarctic Survey Bulletin 25, 121.

Green, T.A.G., Schroeter, B. and Sancho, L.G. (1999) Plant Life in Antarctica, in F.I. Pugnaire and F. Valladares (eds.), Handbook of functional plant ecology, Dekker, New York, U.S.A., pp. 495-543.

Green, T., Schroeter, B. and Seppelt, R. (2000) Effect of temperature, light and ambient UV on the photosynthesis of the moss Bryum argenteum Hedw. in continental Antarctica, in W. Davison, C. Howard-Williams and P. Broady (eds.), Antarctic ecosysystems: modes for wider ecological understanding, New Zealand Natural Sciences, Christchurch, New Zealand, pp. 165-170.

Greenfield, L.G. (1992a) Retention of precipitation nitrogen by Antarctic mosses, lichens and fellfield soils, Antarctic Science 4, 205-206.

Greenfield, L.G. (1992b) Precipitation nitrogen at maritime Signy Island and continental Cape Bird, Antarctica, Polar Biology 11, 649-653.

Gremmen, N.J.M., Huiskes, A.H.L. and Francke, J.W. (1994) Epilithic macrolichen vegetation of the Argentine Islands, Antarctic Peninsula, Antarctic Science 6, 463471.

Hennion, F. and Bouchereau, A. (1998) Accumulation of organic and inorganic solutes in the subantarctic cruciferous species Pringlea antiscorbutica in response to saline and cold stresses, Polar Biology $\mathbf{2 0}$ 281-291.

Hennion, F. and Couderc, H. (1992) Cytogenetical study of Pringlea antiscorbutica R. Br. and Ranunculus moseleyi Hook. f. from the Kerguelen Islands. Antarctic Science 4, 57-58.

Hennion, F. and Couderc, H. (1993) Cytogenetical variability of Ranunculus species from Iles Kerguelen. Antarctic Science 5, 37-40.

Hennion, F. and Martin-Tanguy, J. (1999) Amine distribution and content in several parts of the 
subantarctic endemic species Lyallia kerguelensis (Hectorellaceae), Phytochemistry 52, 247-251.

Hennion, F. and Martin-Tanguy, J. (2000) Amines of the subantarctic crucifer Pringlea antiscorbutica are responsive to temperature conditions, Physiologia Plantarum 109, 232-243.

Hennion, F. and Walton, D.W.H. (1997a) Seed germination of endemic species from Kerguelen phytogeographic zone, Polar Biology 17, 180187.

Hennion, F. and Walton, D.W.H. (1997b) Ecology and seed morphology of endemic species from Kerguelen Phytogeographic Zone, Polar Biology 18, 229235.

Hennion, F., Fiasson, J-L. and Gluchoff-Fiasson, K. (1994) Morphological and phytochemical relationships between Ranunculus species from Iles Kerguelen, Biochemical Systematics and Ecology 22, pp. 533-42.

Holtom, A. and Greene, S.W. (1967) The growth and reproduction of Antarctic flowering plants, Philosophical transactions of the Royal Society of London, series B 252, 323-337.

Honegger, R. (1986) Ultrastructural studies in lichens. II. Mycobiont and phycobiont cell wall surface layers adhering crystalline lichen products in four Parmeliaceae, New Phytologist 125, 659677.

Hovenden, M.J. and Seppelt, R.D. (1995) Uptake of water from the atmosphere by lichens in continental Antarctica, Symbiosis 18, 111-118.

Hovenden, M.J., Jackson, A.E. and Seppelt, R.D. (1994) Field photosynthetic activity of lichens in the Windmill Islands oasis, Wilkes Land, continental Antarctica, Physiologia Plantarum 90, 567576.

Hoyer, K., Karsten, U., Sawall, T. And Wiencke, C. (2001) Photoprotective substances in Antarctic macroalgae and their variation with respect to depth distribution, different tissues and developmental stages, Marine Ecology Progress Series 21, 117-129.

Huiskes, A.H.L., Gremmen, N.J.M. and Francke, J.W. (1997) Morphological effects on the water balance of Antarctic foliose and fruticose lichens, Antarctic Science 9, 36-42.

Huiskes, A.H.L., Lud, D. and Moerdijk-Poortvliet, T.C.W. (2001) Field research on the effects of UV-B filters on terrestrial Antarctic vegetation, Plant Ecology 154, 75-86.

Huiskes, A.H.L., Lud, D., Moerdijk-Poortvliet, T.C.W. and Rozema, J. (1999) Impact of UV-B Radiation on Antarctic Terrestrial Vegetation in J. Rozema (ed.), UV-B and Terrestrial Ecosystems, Backhuys Publishers, Leiden, The Netherlands, pp 313-333.

Hummel, I., Couée, I., El Amrani, A., Martin-Tanguy, J. and Hennion, F. (2002) Involvement of polyamines in root development at low temperature in the subantarctic cruciferous species Pringlea antiscorbutica, Journal of Experimental Botany 53, 1463-1473.

Hummel, I., El Amrani, A., Gouesbet, G., Hennion, F. and Couée, I. (2004a) Involvement of polyamines in the interacting effects of low temperature and mineral supply on Pringlea antiscorbutica (Kerguelen cabbage) seedlings, Journal of Experimental Botany 55, 1125-1134.

Hummel, I., Quemmerais, F., Gouesbet, G., El Amrani, A., Frenot, Y., Hennion, F. and Couée, I. (2004b) Characterization of environmental stress responses during early development of Pringlea antiscorbutica in the field at Kerguelen, New Phytologist 162, 705-715.

Huneck, S., Sainsbury, M., Rickard, T.M.A. and Smith, R.I.L. (1984) Ecological and chemical investigations of lichens from South Georgia and the maritime Antarctic, Journal of the Hattori Botanical Laboratory 56, 461-480.

Ishikura, M., Kato, C. and Maruyama, T. (1997) UV absorbing substances in zooxanthellate and azooxanthellate clams, Marine Biology 128, 649655.

Jackson, A.E. and Seppelt, R.D. (1997) Physiological adaptations to freezing and UV radiation exposure in Prasiola crispa, an Antarctic terrestrial alga, in B. Battaglia, J. Valencia and D.W.H. Walton (eds.), Antarctic Communities: Species, Structure and Survival, Cambridge University Press, Cambridge, U.K., pp. 226-233.

Kappen, L. (1993) Plant activity under snow and ice, with particular reference to lichens, Arctic 46, 297. 302.

Kappen, L. (2000) Some aspects of the great success of lichens in Antarctica, Antarctic Science 12, 314 324.

Kappen, L. and Breuer, M. (1991) Ecological and physiological investigations in continental Antarctic cryptogams. II. Moisture relations and photosynthesis of lichens near Casey Station, Wilkes Land, Antarctic Science 3, 273278. 
Kappen, L. and Valladares, F. (1999) Poikilohydrous autotrophs, in F.I. Pugnaire and F. Valladares (eds.), Handbook of functional plant ecology, Dekker, New York, U.S.A., pp. 9-80.

Kappen, L., Smith, R.I.L. and Meyer, M. (1989) Carbon dioxide exchange of two ecodemes of Schistidium antarctici in continental Antarctica, Polar Biology 9, 415-422.

Karentz, D., Cleaver, J.E. and Michel, D.L. (1991a) Cell survival characteristics and molecular responses of Antarctic phytoplankton to UV-B radiation, Journal of Phycology 27, 326-341.

Karentz, D., McEuen, F.S., Land, M.C. and Dunlap, W.C. (1991b) Survey of mycosporine-like amino acid compounds in Antarctic marine organisms: potential protection from ultraviolet exposure, Marine Biology 108, 157-166.

Kennedy, A.D. (1993) Water as a limiting factor in the Antarctic Terrestrial Environment, Arctic and Alpine Research 25, 308-315.

Kennedy, A.D. (1994) Simulated climate change: a field manipulation study of polar microarthropod community response to global warming, Ecography 17, 131-140.

Kershaw, K.A. and Webber, M.R. (1986) Seasonal changes in the chlorophyll content and quantum efficiency of the moss Brachythecium rutabulum, Journal of Bryology 14, 151158.

King, J.C. and Harangozo, S.A. (1998) Climate change in the western Antarctic Peninsula since 1945: observations and possible causes, Annals of Glaciology 27, 571575.

Lange, O.L. and Kappen, L. (1972) Photosynthesis of lichens from Antarctica, in G.A. Llano (ed.) Antarctic Terrestrial Biology, American Geophysical Union, Washington D.C., U.S.A., pp. 83-95.

Lee, R.E. Jr. and Denlinger, D.L. (1991) (eds.) Insects at Low Temperature, Chapman and Hall, New York, U.S.A., 513 pp.

Leishman, M.R. and Wild, C. (2001) Vegetation abundance and diversity in relation to soil nutrients and soil water content in Vestfold Hills, East Antarctica, Antarctic Science 13, 126134.

Longton, R.E. (1974) Microclimate and biomass in communities of the Bryum association on Ross Island, continental Antarctica, The Bryologist 77, 109127.

Lovelock, C.E., and Robinson, S.A. (2002) Surface reflectance properties of Antarctic moss and their relationship to plant species, pigment composition and photosynthetic function, Plant Cell and Environment 25, 12391250.

Lovelock, C.E., Osmond, C.B. and Seppelt, R.D. (1995b) Photoinhibition in the Antarctic moss Grimmia antarctici Card when exposed to cycles of freezing and thawing, Plant Cell and Environment 18, 13951402.

Lovelock, C.E., Jackson, A.E., Melick, D.R. and Seppelt, R.D. (1995a) Reversible photoinhibition in Antarctic moss during freezing and thawing, Plant Physiology 109, 955961.

Lud, D., Huiskes, A.H.L., Moerdijk, T.C.W. and Rozema, J. (2001b) The effects of altered levels of UVB radiation on an Antarctic grass and lichen, Plant Ecology 154, 87-99.

Lud, D., Buma, A.G.J., Van de Poll, W., Moerdijk, T.C.W. and Huiskes, A.H.L. (2001a) DNA damage and photosynthetic performance in the Antarctic terrestrial alga Prasiola crispa ssp antarctica (Chlorophyta) under manipulated UV-B radiation, Journal of Phycology 37, 459-467.

Margulis, L., Walker, J.C.G. and Rambler, M. (1976) Reassessment of roles of oxygen and ultraviolet light in precambrium evolution, Nature 383, 680.

Marshall, D.J., Newton, I.P. and Crafford, J.E. (1995) Habitat temperature and potential locomotor activity of the continental Antarctic mite, Maudheimia petronia (Acari: Oribatei), Polar Biology 15, 41-46.

Martin, C.E. (1980) Chlorophyll a/b ratios of eleven North Carolina mosses, Bryologist 83, 84-87.

Martin, C.E. and Churchill, S.P. (1982) Chlorophyll concentration and a/b ratios in mosses collected from exposed and shaded habitats in Kansas, Journal of Bryology 12, 297304

McCall, K.K. and Martin, C.E. (1991) Chlorophyll concentrations and photosynthesis in three forest understory mosses in northeastern Kansas, Bryologist 94, 25-29.

Melick, D.R. and Seppelt, R.D. (1992) Loss of soluble carbohydrates and changes in freezing point of Antarctic bryophytes after leaching and repeated freeze-thaw cycles, Antarctic Science 4, 399-404.

Melick, D.R. and Seppelt, R.D. (1994a) The effect of hydration on carbohydrate levels, pigment content and freezing point of Umbilicaria decussata at a continental Antarctic locality, Cryptogamic Botany 4, 212217.

Melick, D.R. and Seppelt, R.D. (1994b) Seasonal investigations of soluble carbohydrates and pigment 
levels in Antarctic bryophyte and lichens, The Bryologist 97, 13-19.

van der Merwe, M., Chown, S.L. and Smith, V.R. (1997) Thermal tolerance limits in six weevil species (Coleoptera, Curculionidae) from subantarctic Marion Island, Polar Biology 18, 331-336.

Meykamp, B.B., Doodeman, G. and Rozema, J. (2001) The response of Vicia faba to enhanced UV-B radiation under low and near ambient PAR levels, Plant Ecology 154, 135146

Montiel, P., Smith, A. and Keiller, D. (1999) Photosynthetic responses of selected Antarctic plants to solar radiation in the southern maritime Antarctic, Polar Research 18, 229-235.

Nakanishi, S. (1979) On the variation of leaf characters of an Antarctic moss, Bryum inconnexum. Memoirs of the National Institute of Polar Research, 47-57.

Nakatsubo, T. (2002) Predicting the impact of climatic warming on the carbon balance of the moss Sanionia uncinata on a maritime Antarctic island, Journal of Plant Research 115, 99-106.

Newsham, K.K., Hodgson, D.A., Murray, A.W.A., Peat, H.J. and Smith, R.I.L. (2002) Response of two Antarctic bryophytes to stratospheric ozone depletion, Global Change Biology 8, 972983.

Newsham, K.K. (2003) UV-B radiation arising from stratospheric ozone depletion influences the pigmentation of the Antarctic moss Andreaea regularis, Oecologia 135, 327-331.

Norton, R.A. (1994) Evolutionary aspects of oribatid mite life histories and consequences for the origin of the Astigmata, in M. Houck (ed.), Ecological and evolutionary analyses of life-history patterns Chapman and Hall, New York, U.S.A., pp. 99-135.

Nybakken, L., Aubert, S. and Bilger, W. (2004b) Epidermal UV-screening of arctic and alpine plants along a latitudinal gradient in Europe, Polar Biology 27, 391-398.

Nybakken, L., Bilger, W., Johanson, U., Björn, L.O., Zielke, M. and Solheim, B. (2004a) Epidermal UVscreening in vascular plants from Svalbard (Norwegian Arctic), Polar Biology 27, 383390.

Pakkr, H., Martins, R.S.T., Boelen, P., Buma, A.G.J., Nikaido, O. and Breeman, A.M. (2000) Effects of temperature on the photoreactivation of ultraviolet-B induced DNA damage in Palmaria palmata (Rhodophyta), Journal of Phycology 36, 334341.

Pannewitz, S., Schlensog, M., Green, T.G.A., Sancho, L. and Schroeter, B. (2003) Are lichens active under snow in continental Antarctica? Oecologia 135, 30-38.

Pickup, J. and Rothery, P. (1991) Water-loss and anhydrobiotic survival in nematodes of Antarctic fellfields, Okos 61, 379-388.

Post, A. and Larkum, A.W.D. (1993) UV absorbing pigments, photosynthesis and UV exposure in Antarctica: Comparison of terrestrial and marine algae, Aquatic Botany 45, 231-243.

Quayle, W.C., Peck, L.S., Peat, H., Ellis-Evans, J.C. and Harrigan, P.R. (2002) Extreme responses to climate change in lakes, Science 295, 645.

Quayle, W.C., Convey, P., Peck, L.S., Ellis-Evans, C.J., Butler, H.G. and Peat, H.J. (2003) Ecological responses of maritime Antarctic lakes to regional climate change, in E. Domack, A. Burnett, A Leventer, P. Convey, M. Kirby and R. Bindschadler (eds.), Ecological responses of maritime Antarctic lakes to regional climate change. Antarctic Research Series vol. 79, American Geophysical Union, U.S.A., pp. 159-170.

Rastorfer, J.R. (1972) Comparative physiology of four west Antarctic mosses, Antarctic Research Series 20, 143161.

Reyes, M.A., Corcuera, L.J. and Cardemil, L. (2003) Accumulation of HSP70 in Deschampsia antarctica Desv. leaves under thermal stress, Antarctic Science 15, 345-352.

Ring, R.A. and Danks, H.V. (1994) Desiccation and cryoprotection: overlapping adaptations, Crye Letters 15, 181190.

Robberecht, R. and Caldwell, M.M. (1978) Leaf epidermal transmittance of ultraviolet radiation and its implications for plant sensitivity to ultraviolet radiation induced injury, Oecologia 32, 277287.

Robinson, S.A., Turnbull, J.A., and Lovelock, C.E (2005) Impact of changes in natural ultraviolet radiation on pigment composition, physiological and morphological characteristics of the Antarctic moss, Grimmia antarctici, Global Change Biology 11, 476-489

Robinson, S.A., Wasley, J. and Tobin, A.K. (2003) Living on the edge - plants and global change in continental and maritime Antarctica, Global Change Biology 9, 1681-1717.

Robinson, S.A., Wasley, J., Popp, M. and Lovelock, C.E. (2000) Desiccation tolerance of three moss species from continental Antarctica, Australian Journal of Plant Physiology 27, 379388. 
Robinson, S.A., Wasley, J., Turnbull, J., Lovelock, C.E. (2001) Antarctic moss coping with the ozone hole, Proceedings of the $12^{\text {th }}$ International Congress on Photosynthesis, CSIRO publishing, Canberra, Australia.

Rozema, J., R. Broekman, D. Lud, A.H.L. Huiskes, T.C.W. Moerdijk-Poortvliet, N. de Bakker, B. Meijkamp and A. van Beem (2001) Consequences of depletion of stratospheric ozone for terrestrial Antarctic ecosystems: the response of Deschampsia antarctica to enhanced UV-B radiation in a controlled environment, Plant Ecology 154, 101115.

Ruhland, C.T. and Day, T.A. (2000) Effects of ultraviolet-B radiation on leaf elongation, production and phenylpropanoid concentrations of Deschampsia antarctica and Colobanthus quitensis in Antarctica, Physiologia Plantarum 109, 244-251.

Ruhland, C.T. and Day, T.A. (2001) Size and longevity of seed banks in Antarctica and the influence of ultraviolet-B radiation on survivorship, growth and pigment concentrations of Colobanthus quitensis seedlings, Environmental and Experimental Botany 45, 143154.

Schlensog, M. and Schroeter, B. (2000) Poikilohydry in Antarctic cryptogams and its influence on photosythetic performance in mesic and xeric habitats, in P. Broady (ed.), Antarctic Ecosystems: models for wider ecological understanding, New Zealand Natural Sciences, New Zealand, pp. 175182.

Schlensog, M., Schroeter, B., Sancho, L.G., Pintado, A. and Kappen, L. (1997) Effect of strong irradiance on photosynthetic performance of the melt-water dependent cyanobacterial lichen Leptogium puberulum (Collemataceae) Hue from the maritime Antarctic, Bibliotheca Lichenologia 67, 235-246.

Schroeter, B. and Scheidegger, C. (1995) Water relations in lichens at subzero temperatures: structural changes and carbon dioxide exchange in the lichen Umbilicaria aprina from continental Antarctica, New Phytologist 131, 273285.

Schroeter, B., Green, T.G.A., Kappen, L. and Seppelt, R.D. (1994) Carbon dioxide exchange at subzero temperatures. Field measurements on Umbilicaria aprina in Antarctica, Cryptogamic Botany 4, 233 241.

Schroeter, B., Kappen, L., Green, T.G.A. and Seppelt, R.D. (1997) Lichens and the Antarctic environment: Effects of temperature and water availability on photosynthesis, in W.B. Lyons, C. Howard-Williams and I. Hawes (eds.), Ecosystem processes in Antarctic ice-free landscapes, Balkema, Rotterdam, The Netherlands, pp. 103-118.

Searles, P.S., Kropp, B.R., Flint, S.D. and Caldwell, M.M. (2001) Influence of solar UV-B radiation on peatland microbial communities of southern Argentina, New Phytologist 152, 213-221.

Sinclair, B.J. (1999) Insect cold tolerance: how many kinds of frozen? European Journal of Entomology 96, 157164.

Sinclair, B.J., Addo-Bediako, A. and Chown, S.L. (2003a) Climatic variability and the evolution of insect freeze tolerance, Biological Reviews 78, 181195.

Sinclair, B.J., Vernon, P., Klok, C.J. and Chown, S.L. (2003b) Insects at low temperatures: an ecological perspective, Trends in Ecology and Evolution 18, 257-262.

Sinclair, B.J., Klok, C.J., Scott, M.B., Terblanche, J.S. and Chown, S.L. (2003c) Diurnal variation in supercooling points of three species of Collembola from Cape Hallett, Antarctica, Journal of Insect Physiology 49, 1049-1061.

Skvarca, P., Rack, W., Rott, H. and Ibarzábal y Donángelo, T. (1998) Evidence of recent climatic warming on the eastern Antarctic Peninsula, Annals of Glaciology 27, 628632

Smith, R.I.L. (1984) Terrestrial Plant Biology of the Subantarctic and the Antarctic, in R.M. Laws (ed.), Antarctic Ecology Volume 1, Academic Press, London, pp. 61-162.

Smith, R.I.L. (1988) Recording bryophyte microclimate in remote and severe environments, In J.M. Glime (ed.), Methods in Bryology, Hattori Botanical Laboratory, Nichinan, Japan, pp. 275-284.

Smith, R.I.L. (1990) Signy Island as a paradigm of biological and environmental change in Antarctic terrestrial ecosystems, in K.R. Kerry and G. Hempel (eds.), Antarctic Ecosystems, Ecological Change and Conservation, Springer-Verlag, Berlin, Germany.

Smith, R.I.L. (1999) Biological and environmental characteristics of three cosmopolitan mosses dominant in continental Antarctica, Journal of Vegetation Science 10, 231242.

Smith, R.I.L. (2001) Plant colonization response to climate change in the Antarctic, Folia Facultatis Scientiarum Naturalium Universitatis Masarykiana Brunensis, Geographia, 25, 19-33. 
Smith, V.R. (2002) Climate change in the subantarctic: an illustration from Marion Island, Climatic Change 52, 345357.

Smith, V.R. (2005) Moisture, carbon and inorganic nutrient controls of soil respiration at a subantarctic island, Soil Biology and Biochemistry 37, 81-91.

Smith, V.R. and Steenkamp, M. (1992) Macroinvertebrates and litter nutrient release on a sub-Antarctic island, South African Journal of Botany 58, 105116.

Solhaug, A.A. and Gauslaa, Y. (1996) Parietin, a photoprotective secondary product of the lichen Xanthoria parietina, Oecologia 108, 412418.

Sømme, L. (1986) Ecology of Cryptopygus sverdrupi (Insecta: Collembola) from Dronning Maud Land, Antarctica, Polar Biology 6, 179-184.

Strathdee, A.T., Bale, J.S., Strathdee, F.C., Block, W.C., Coulson, S.J., Webb, N.R. and Hodkinson, I.D. (1995) Climatic severity and the response to temperature elevation of Arctic aphids, Global Change Biology 1, 23-28.

Strullu, D.G., Frenot, Y., Maurice, D., Gloaguen, J.C. and Plenchette, C. (1999) Première contribution à l'étude des mycorhizes des îles Kerguelen, Comptes Rendus de l'Académie des Sciences de Paris, Sciences de la Vie 322, 771777.

Sullivan, J. and Rozema, J. (1999) UV-B effects on terrestrial plant growth and photosynthesis, in J. Rozema (ed.), Stratospheric ozone depletion, the effects of enhanced UV-B radiation on terrestrial ecosystems, Backhuys, Leiden, The Netherlands, pp. 39-57.

Swanson, A. and Fahselt, D. (1997) Effects of ultraviolet on polyphenolics of Umbilicaria americana, Canadian Journal of Botany 75, 284289.

Swanson, A., Fahselt, D. and Smith, D. (1996) Phenolic levels in Umbilicaria americana in relation to enzyme polymorphism, altitude and sampling date, Lichenologist 28, 331-339.

Tarnawski, M., Melick, D., Roser, D., Adamson, E., Adamson, H. and Seppelt, R. (1992) In situ carbon dioxide levels in cushion and turf forms of Grimmia antarctici at Casey Station, East Antarctica, Journal of Bryology 17, 241249.

Teramura, A.H. and Ziska, L.H. (1996) Ultraviolet-B radiation and photosynthesis, in N.R. Baker (ed.), Photosynthesis and the environment, Kluwer Academic Publishers, Dordrecht, The Netherlands, pp. 435-450.

Verhoeven, A.S., Adams, W.W. and Demmig-Adams, B. (1998) 2 forms of sustained xanthophyll cycledependent energy-dissipation in overwintering Euonymus-Kiautschovicus, Plant, Cell and Environment 21, 893903.

Vining, E.C., Crafts-Brandner, S.J. and Day, T.A. (1997) Photosynthetic acclimation of antarctic hair grass (Deschampsia antarctica) to contrasting temperature regimes, Bulletin of the Ecological Society of America 78, 327.

Walton, D.W.H. (1976) Dry matter production in Acaena (Rosaceae) on a subantarctic island, Journal of Ecology 64, 399415.

Walton, D.W.H. (1977) Studies on Acaena (Rosaceae) I. Seed germination, growth and establishment in A. magellanica (Lam.) Vahl and A. tenera Alboff, British Antarctic Survey Bulletin 45, 29-40.

Walton, D.W.H. (1982) The Signy Island terrestrial reference sites. XV. Microclimate monitoring, 19724,British Antarctic Survey Bulletin 55, 111-126.

Wasley, J. (2004) The effect of Climate Change on Antarctic Terrestrial Flora. PhD Thesis, University of Wollongong, Australia.

Wasley, J., Robinson, S.A., Popp, M., Lovelock, C.E. (2006a) Climate change manipulations show Antarctic flora is more strongly affected by elevated nutrients than water, Global Change Biology (in press).

Wasley, J., Robinson, S.A., Lovelock, C.E. and Popp, M. (2006b) Some like it wet - biological characteristics underpinning tolerance of extreme water events in Antarctic bryophytes, Functional Plant Biology, 33, 443455.

Webby, R.F. and Markham K.R. (1994) Isoswertiajaponin2"-O-beta-arabinopyranoside and other flavone-C-glycosides from the Antarctic grass Deschampsia Antarctica, Phytochemistry 36, 1323 1326.

Webby, R.F., Markham, K.R. and Smith, R.I.L. (1996) Chemotypes of the Antarctic moss Bryum algens 
delineated by their flavonoid constitutents, Biochemical Systematics and Ecology 24, 469475.

Wharton, D.A. (1995) Cold tolerance strategies in nematodes, Biological Reviews 70, 161185.

Wharton, D.A. and Block, W. (1993) Freezing tolerance in some Antarctic nematodes, Functional Ecology 7, 578584 .

Wharton, D.A. and Block, W. (1997) Differential scanning calorimetry studies on an Antarctic nematode (Panagrolaimus davidi) which survives intracellular freezing, Cryobiology 34, 114-121.

Wharton, D.A. and Ferns, D.J. (1995) Survival of intracellular freezing by the Antarctic nematode Panagrolaimus davidi, Journal of Experimental Biology 198, 1381-1387.

Wilson, M.E. (1990) Morphology and photosynthetic physiology of Grimmia antarctici from wet and dry habitats, Polar Biology 10, 337-341.

Worland, M.R. (1996) The relationship between body water content and cold tolerance in the Arctic collembolan Onychiurus arcticus (Collembola: Onychiuridae), European Journal of Entomology $\mathbf{9 3}$ 341-348.

Worland, M.R. and Convey, P. (2001) Rapid cold hardening in Antarctic microarthropods, Functional Ecology 15, 515525.

Worland, M.R., Block, W. and Oldale, H. (1996). Ice nucleation activity in biological materials with examples from Antarctic plants. CryoLetters 17, 31-38.

Worland, M.R., Grubor-Lajsic, G. and Montiel, P.O. (1998) Partial desiccation induced by sub-zero temperatures as a component of the survival strategy of the Arctic collembolan Onychiurus arcticus (Tullberg), Journal of Insect Physiology 44, 214219.

Wynn-Williams, D.D. (1994) Potential effects of Ultraviolet radiation on Antarctic primary terrestrial colonizers: cyanobacteria, algae and cryptogams, Antarctic Research Series 62, 243257.

Xiong, F. and Day, T. (2001) Effect of solar ultraviolet-B radiation during springtime ozone depletion on photosynthesis and biomass production of Antarctic vascular plants, Plant Physiology 125, 738751.

Xiong, F.S., Mueller, E.C. and Day, T.A. (2000) Photosynthetic and respiratory acclimation and growth response of Antarctic vascular plants to contrasting temperature regimes, American Journal of Botany 87, 700710.

Xiong, F., Ruhland, C. and Day, T. (1999) Photosynthetic temperature response of the Antarctic vascular plants Colobanthus quitensis and Deschampsia antarctica, Physiologia Plantarum 106, 276286.

Zachariassen, K.E. (1985) Physiology of cold tolerance in insects, Physiological Reviews 65, 799832.

Zuñiga, G.E., Alberdi, M. and Corcuera, L.J. (1996) Non-structural carbohydrates in Deschampsia antarctica Desv. from South Shetland Islands, maritime Antarctic, Environmental and Experimental Botany 36, 393398.

Zuñiga, G.E., Alberdi, M., Fernandez J., Montiel P. and Corcuera, L.J. (1994) Lipid content in leaves of Deschampsia antarctica from the maritime Antarctic, Phytochemistry 37, 669672. 